\title{
Paleoenvironment, Geochemistry, and Pore Characteristics of the Postmature to Overmature Organic-Rich Devonian Shales in Guizhong Depression, Southwestern China
}

\author{
Yanqi Zhang $\mathbb{D}^{1,2}$ Li Liu, ${ }^{1}$ Changxi Geng, ${ }^{1,2}$ Zhuang Cheng, ${ }^{3}$ and Xinxin Fang $\mathbb{D}^{4,5}$ \\ ${ }^{1}$ School of Geosciences, Jilin University, Changchun 130061, China \\ ${ }^{2}$ Daqing Drilling Engineering Company, Daqing Oilfield Co. Ltd., Daqing 163458, China \\ ${ }^{3}$ Daqing Drilling \& Geological Logging No. 1 Company, Daqing 163458, China \\ ${ }^{4}$ Institute of Geomechanics, Chinese Academy of Geological Sciences, Beijing 100081, China \\ ${ }^{5}$ Key Laboratory of Paleomagnetism and Tectonic Reconstruction, Ministry of Natural Resources, Beijing 100081, China
}

Correspondence should be addressed to Yanqi Zhang; 183268205@qq.com and Xinxin Fang; 8530324@qq.com

Received 11 August 2021; Accepted 12 November 2021; Published 30 December 2021

Academic Editor: Steffen Berg

Copyright (C) 2021 Yanqi Zhang et al. This is an open access article distributed under the Creative Commons Attribution License, which permits unrestricted use, distribution, and reproduction in any medium, provided the original work is properly cited.

Investigating shale pore characteristics has deepened our understanding of shale reservoir, while that of postmature-overmature shales is yet to be revealed, which is especially critical for shale gas evaluation in southern China. Ten Middle-Upper Devonian organic-rich shale samples were collected from well GY-1 in the Guizhong Depression, and the paleoenvironment, geochemistry, and pore system were analyzed with a series of experiments, including trace element analysis, X-ray diffraction (XRD), field emission scanning electron microscopy (FESEM), low-pressure $\mathrm{N}_{2}$ adsorption, and source rock geochemistry. Results show that the Middle-Upper Devonian shales in the Guizhong Depression are organic-rich mudstones with TOC ranging from $0.14 \%$ to $6.21 \%$, which is highest in the Nabiao Formation $\left(D_{2} n\right)$ and Lower Luofu Formation $\left(D_{2} l\right)$ that were deposited in the anoxic and weak hydrodynamic deep-water shelf. They are thermally postmature to overmature with equivalent vitrinite reflectance $\left(\mathrm{EqVR}_{\mathrm{o}}\right)$ of $3.40 \% \sim 3.76 \%$ and type I kerogen. The lithofacies in $D_{2} n$ and $D_{2} l$ are primarily siliceous/argillaceous mixed shale as well as a few siliceous argillaceous shales and argillaceous siliceous shales as well. Organic matter- (OM-) hosted pores within bitumen are primary storage volume, rather than inorganic pores (interparticle and intraparticle) which are rare. The total helium porosity of samples varies between $1.20 \%$ and $4.49 \%$, while total surface area and pore volume are $2.39-14.22 \mathrm{~m}^{2} / \mathrm{g}$ and $0.0036-0.0171 \mathrm{ml} / \mathrm{g}$, respectively. Porosity, pore surface area, and pore volume are in accordance with increasing TOC, $R_{\mathrm{o}}$, and siliceous mineral contents. Considerable OM-macropores are found in shales with $R_{\mathrm{o}}$ $>3.6 \%$ in our study which demonstrates that the porosity at postmature to overmature stage $\left(R_{0}=3.5-4.0 \%\right)$ does not change fundamentally. The high level of maturity is not considered the main controlling factor that affects shale gas content, and more attention should be paid to preservation conditions in this area.

\section{Introduction}

Shales have attracted significant attention in the past few years because of their emergence as unconventional hydrocarbon reservoirs [1-3]. Identifying and producing reserves from shales in south China have gained considerable exploration interest and activity, which have made significant progress $[4,5]$. Unlike conventional sandstone and carbonate reservoirs with microscale pores, shales are typically domi- nated by nanoscale pores [6]. The pore structure characterization using various techniques has gained a high research priority as they are essential in a potential shale reservoir evaluation. The direct imaging methods, e.g., CT scan, field emission scanning electron microscopy (FESEM), focused ion beam-scanning electron microscopy (FIB-SEM), and transmission electron microscopy (TEM) [7-11], provide information on pore size, pore morphology, and connectivity of the pore networks. The indirect methods, e.g., mercury 
injection porosimetry (MIP), low-pressure gas adsorption $\left(\mathrm{CO}_{2}\right.$ and $\left.\mathrm{N}_{2}\right)$, and small-angle and ultra-small-angle neutron scattering (SANS and USANS), can be employed to investigate porosity, specific surface area, and pore size distribution $[10,12,13]$. Organic matter-hosted pores have been identified as an important pore system in gas shales [9, 14-18]. Thermal maturity has been considered by previous studies as one of the critical controllers of organic pore growth $[1,13,19-23]$. Researchers have tried to restore the hydrocarbon generation process and associated organic pore growth through pyrolysis, which can cover the weakness of measurements mentioned above in pore system characterization and prediction [24-29]. However, pyrolysis differs remarkably with geological conditions in temperature, pressure, medium, heating model, etc. Many investigations reported that nanoscale pores were generated due to kerogen degradation with increasing thermal maturity, but commonly shrank as a result of high temperature and pressure and no available oil cracking into gas in deep basin $[9,13$, $14,30]$. The conversation among micropore, mesopore, and macropore was found, and an evolution model of porosity with thermal maturity was established [13, 21, 31]. However, the pyrolysis results typically require the constraint from high- to over-high-mature natural shale samples. Therefore, characterizing the pore system of such high-mature Devonian shales in the Guizhong Depression can provide insight into the shale gas resource assessment in China.

Dian-Qian-Gui Basin is an important petroliferous basin in south China with high petroleum exploration potential [32]. The Devonian marine deposits in the Guizhong Depression are characterized by good hydrocarbon accumulation conditions and considerable petroleum resource potential [33-36]. GY-1 well was drilled at the northwest of the Guizhong Depression to investigate the occurrence of the Devonian shale, understand its geochemical characteristics and storage capacity, and evaluate shale gas resource potential. It is the first well drilling all shales in the Devonian with a completion depth of 1205.5 m (Lower Devonian Lianhuashan Formation). Coring for the whole well section provides considerable evidence for us to analyze hydrocarbon generation potential and reservoir quality. In this study, we will (1) investigate geochemistry and pore system of Devonian shales in the Guizhong Depression that can be further compared with organic-rich shales from other basins in South China and other countries and (2) discuss the organic matter-hosted pores in postmature to overmature stage and the contributors to their development.

\section{Geological Settings}

The Dian-Qian-Gui Basin is situated in southwest China in the provinces of Yunnan (Dian), Guizhou (Qian), and Guangxi (Gui) (Figure 1). It lies in the northern Nanpanjiang orogenic fold zone along the southwest margin of the Yangtze (South China) Precambrian craton [37, 38] at the join of the Tethyan Himalayan and Pacific Ocean tectonic plates [39, 40].

Guizhong Depression in the north-central Guangxi is a secondary structural unit in the northeastern Dian-Qian-
Gui Basin with an area of $4.6 \times 10^{4} \mathrm{~km}^{2}$. Structurally, it is located at the joint of the southwest margin of Yangtze block and South China Caledonian fold belt, which is sandwiched between the Pacific tectonism and the Tethys tectonism [41].

The Guizhong Depression is adjacent to the Xuefengshan Uplift in the north, Qiannan Depression in the northwest, Guilin Depression and Dayaoshan Uplift in the east, and Nanpanjiang Depression and Luodian Fault Depression in the west. It is bounded by the Longsheng-Yongfu Fault, the Nandan-Duan Fault in the west, and the Dayaoshan Fault in the east. The depression can be divided into several sags and salients (Figure 1).

Guizhong Depression was a large marine deposition center during Late Paleozoic due to the Caledonian movement, which is currently a residual basin filled by the Upper Paleozoic and Triassic [41]. During the Lianhuashan and Nagaoling period, terrigenous clastic sandstone with silty mudstone was deposited in the Guizhong Depression. The paleo-Tethyan extensional rift during the late Devonian resulted in regional tension with deposition as well as the growth of NWtrending and NNE-NE-trending faults. Meanwhile, the transgression extended from south to north, forming the platformbasin sedimentary framework, e.g., the basin facies mainly occurred at the western depression, depositing Yilan and Tangding siltstone, limestone, and black marl. The increasing rifting during the Middle Devonian gave rise to the growth of NW-trending and nearly NS-trending faults and high relative sea level, enlarging platform and basin and forming alternation of platform and basin. Consequently, Nabiao and Luofu black carbonaceous shale, siliceous shale, and marl were deposited in semideep water to deep water [41].

The Upper Devonian Liujiang Formation in the GY-1 well is mainly limestone and siliceous rocks in the upper section and calcareous mudstone interbedded with thin argillaceous limestone in the lower section. The Middle Devonian Luofuyang Formation is calcareous mudstone and thin gray marl, while the Nabiao Formation is characterized by calcareous mudstone with decreasing calcareous content from the top to the bottom with considerable tentaculites. The Tangding Formation is dominated by gray-light gray silty mudstone with marl lenses and framboidal pyrite at the top. The Lower Devonian is typically light gray fine sandstone and dark grey silty mudstone. The thickness of the Lower Liujiang Formation, Luofu Formation, Nabiao Formation, and the Upper Tangding Formation in the GY-1 well is over $600 \mathrm{~m}$, which is dominated by carbonaceous shale and marl depositing in deep-water shelf and shallow-water shelf (Figure 2).

\section{Samples and Methods}

Ten core samples from the GY-1 well were collected to perform trace elements analysis, X-ray diffraction (XRD), field emission scanning electron microscopy (FESEM), lowpressure $\mathrm{N}_{2}$ adsorption, and source rock geochemistry (total organic carbon (TOC), kerogen microscopic examination, and bitumen reflectance).

3.1. Trace Element Analysis. Samples were cleaned in an ultrasound bath and then were oven-dried. After that, they 


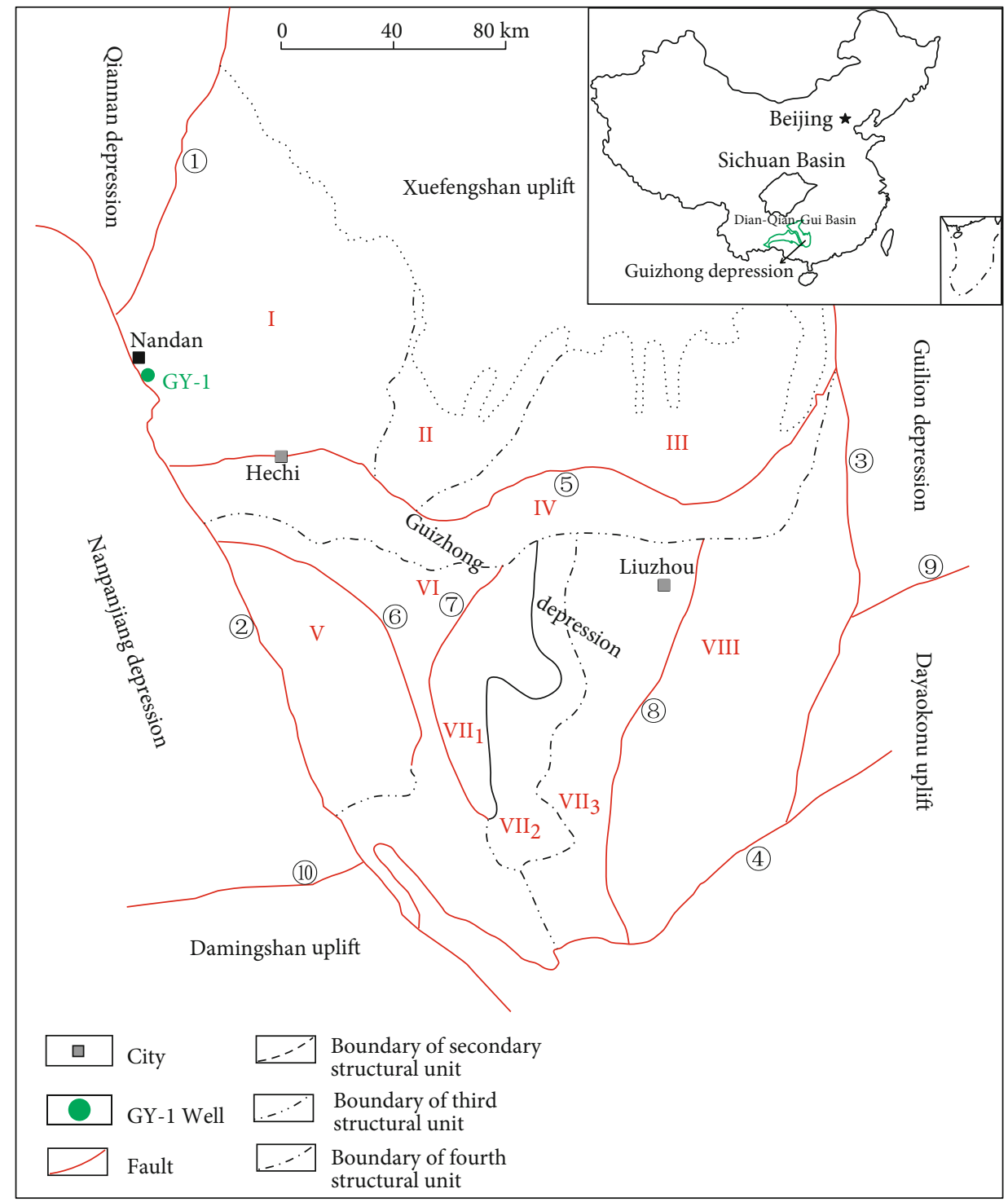

Structural unit: I-Huanjiang sag II-Luocheng salient III-Liucheng slope IV-Yishanfault-sag V-Mashanfault-salient VI-Hongdu sag VII-Liujiang Salient VII ${ }_{1}=$ Datang anticline belt $\mathrm{VII}_{2}$-Heshan syncline belt VII ${ }_{3}$-Liuzhou anticline belt VII-Xiangzhou Sag

Fault: (1) Sandu fault (2) Nandan-Kunlun guan fault (3) Longshegn-Yongfu fault (4) Pingxiang-Dali fault

(5) Hechi-Liucheng fault (6) Jiagui-Gupeng fault (7) Limiao-Qiaoxian fault (8) Liuzhou-Laibin fault

(9) Lipu fault (10) Xialei-Lingma fault

Figure 1: Location and structural units of the Guizhong Depression.

were disaggregated into grains ( $<200$ meshes) by physical crushing with an agate mortar. The measurement was conducted using the acid dissolution method in the State Key Laboratory of Isotope Geochemistry, Guangzhou Institute of Geochemistry, Chinese Academy of Sciences. Dried powders were burned in the oven at $700^{\circ} \mathrm{C}$ for 3 hours to remove organic compounds. $0.37-0.45 \mathrm{mg}$ of remaining was dissolved using $\mathrm{HNO}_{3}, \mathrm{HF}$, and $\mathrm{HClO}_{4}$ in the PTFE sampling bottom. The analysis was performed using A PEElan6000 ICP-MS.

3.2. X-Ray Diffraction (XRD) Analysis. The XRD experiment was performed using a ZJ207 Bruker D8 advance X-ray diffractometer following the oil and gas industry standards
(SY/T5463-2010). The shale samples were crushed smaller than 300 mesh sizing and hand-mixed with ethanol in a mortar and pestle and then smear-mounted on glass slides for XRD analysis. The X-ray diffractometer with $\mathrm{Cu} \mathrm{X}$-ray tube operated at $40 \mathrm{kV}$ and $30 \mathrm{~mA}$ and scanned from $2^{\circ}$ to $70^{\circ}$ at a step of $0.02^{\circ}$, and the data was semiquantified using Jade $^{\circledR} 6.0$ software.

3.3. Geochemistry of Source Rocks. Kerogen microscopic examination, TOC, and bitumen reflectance measurements were carried out in the Experimental Research Center of Wuxi Research Institute of Petroleum Geology, SINOPEC. Kerogen maceral in the sediments was identified using 


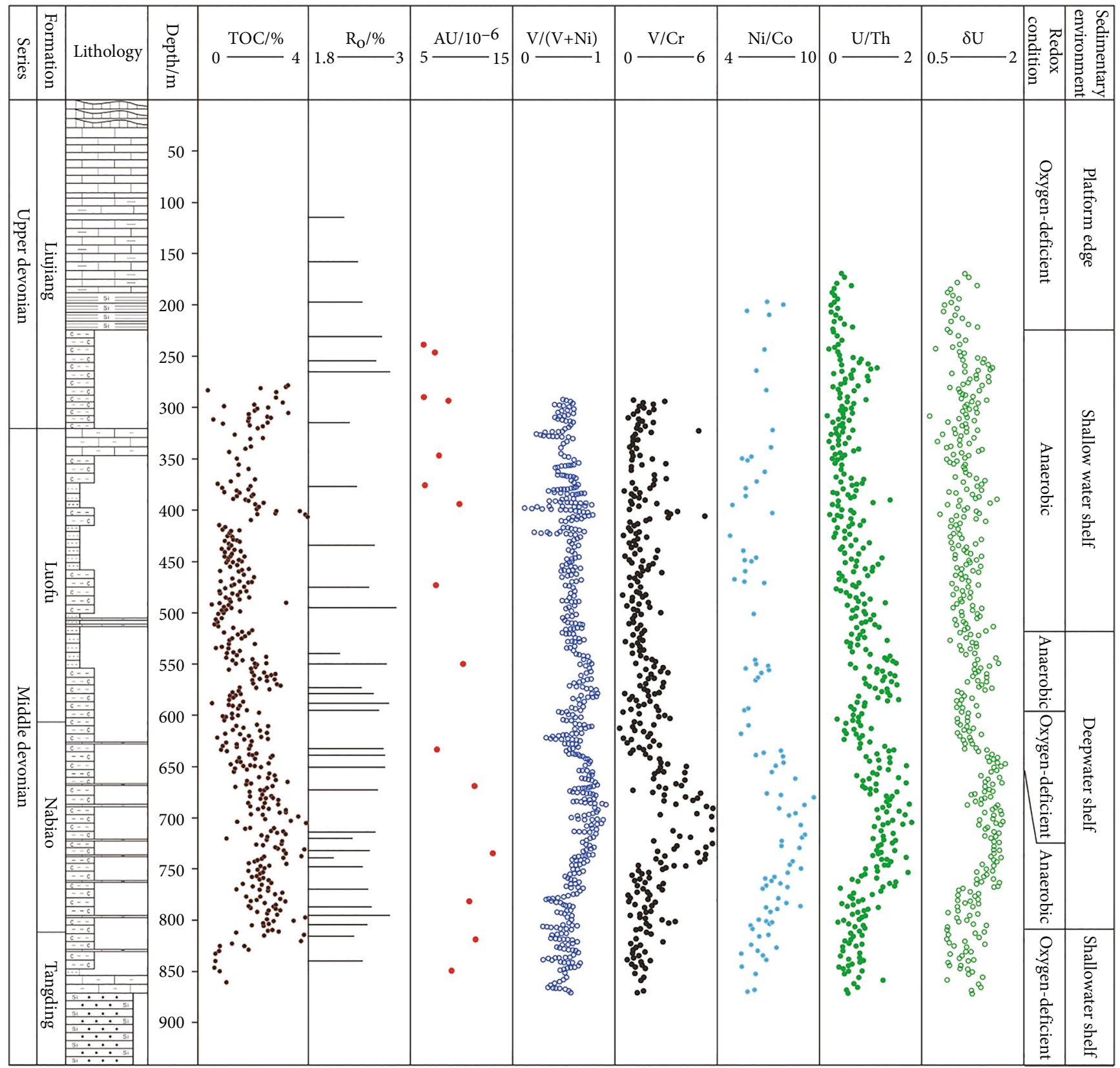

FIgURE 2: Stratigraphic column of the GY-1 well. The trace element data and the paleoenvironment are explained.

LEICA DMRX Polarization microscope DM4500P, while the kerogen type was determined using the percentage compositions of individual maceral and corresponding weighting coefficients following the Chinese National Standards SY/T 5125-2014. For TOC analysis, each sample $(0.10 \mathrm{~g})$ was prepared with $12.5 \% \mathrm{HCl}$ to remove carbonates in a sterilized crucible and was washed in distilled water every half an hour for three days and then were oven-dried. TOC analysis was conducted in a LECO CS-230 carbon analyzer following the Chinese National Standards GB/T19145-2003. With no vitrinite in the samples, the optical feature and bitumen reflectance was determined through observing polished sur- faces of samples using MSP 200 microphotometer following the Chinese National Standards SY/T5124-2012.

3.4. Field Emission Scanning Electron Microscopy (FESEM). The FESEM observation was carried out at China University of Petroleum, Beijing. Shale samples were cut into about one-centimeter square, which was polished to produce flat surfaces using dry emery paper. After that, they were milled by sputtering away shale material via momentum transfer with a focused $30 \mathrm{kV}$ beam of argon ions in a focused ion beam (FIB) system. Representative samples were coated with carbon to produce a conductive surface, which was inspected 


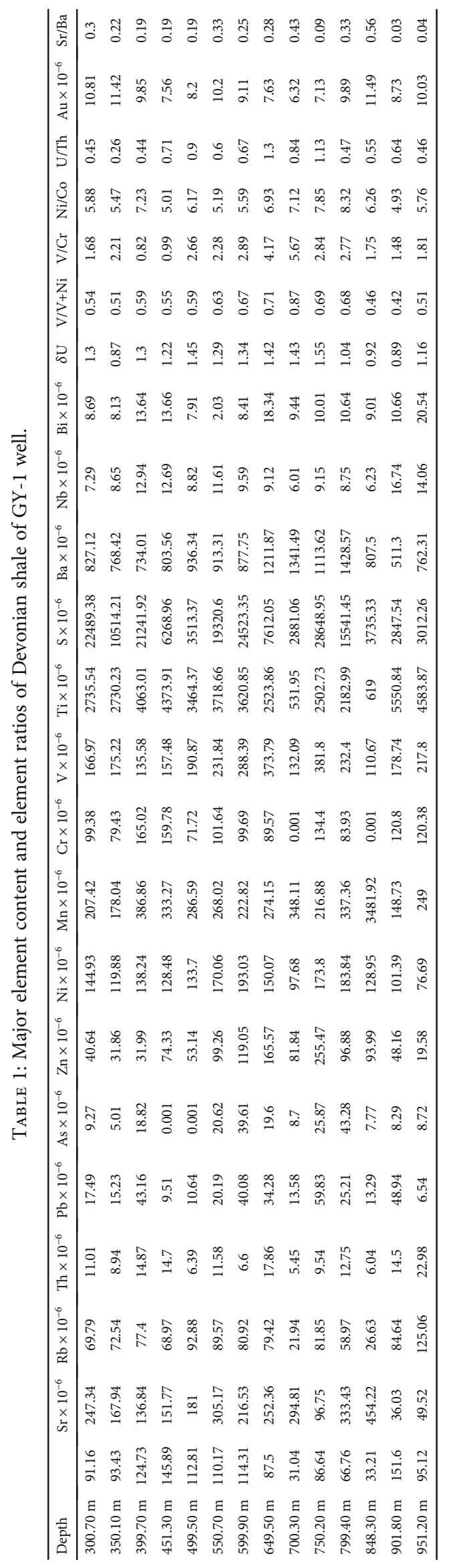


TABLE 2: Kerogen microscopic composition and determined kerogen type index.

\begin{tabular}{|c|c|c|c|c|c|c|c|c|}
\hline \multirow{2}{*}{ Depth (m) } & \multirow{2}{*}{ Formation } & \multicolumn{2}{|c|}{ Sapropelinite (\%) } & \multirow{2}{*}{$\begin{array}{c}\text { Exinite (\%) } \\
\text { Benthic algae }\end{array}$} & \multirow{2}{*}{ Vitrinite (\%) } & \multirow{2}{*}{ Inertinite (\%) } & \multirow{2}{*}{$\mathrm{TI}$} & \multirow{2}{*}{ Type } \\
\hline & & Amorphous solid & Alginite & & & & & \\
\hline 231 & $D_{3} l$ & 56 & 18 & 26 & - & - & 87 & I \\
\hline 255 & $D_{3} l$ & 58 & 17 & 25 & - & - & 87.5 & I \\
\hline 475 & $D_{2} l$ & 63 & 15 & 22 & - & - & 89 & I \\
\hline 495 & $D_{2} l$ & 64 & 18 & 18 & - & - & 91 & I \\
\hline 579 & $D_{2} l$ & 65 & 14 & 21 & - & - & 89.5 & I \\
\hline 595 & $D_{2} l$ & 62 & 14 & 24 & - & - & 88 & I \\
\hline 639 & $D_{2} n$ & 67 & 15 & 18 & - & - & 91 & I \\
\hline 651 & $D_{2} n$ & 62 & 13 & 25 & - & - & 87.5 & I \\
\hline 739 & $D_{2} n$ & 65 & 15 & 20 & - & - & 90 & I \\
\hline 795 & $D_{2} n$ & 70 & 14 & 16 & - & - & 92 & I \\
\hline
\end{tabular}

Note: TI $=100 \times a+100 \times b 1+50 \times b 2+10 \times c 1+(-75) \times c 2+(-100) \times \mathrm{d}$, where TI is the kerogen type index, $a$ is the sapropelinite (\%), $b 1$ is the resinite (\%), $b 2$ is the cutinite, suberinite, sporinite, amorphous solid, and benthic algae (\%), $c 1$ is the perhydrous vitrinite (\%), $c 2$ is the normal vitrinite (\%), and $d$ is the fusinite (\%).

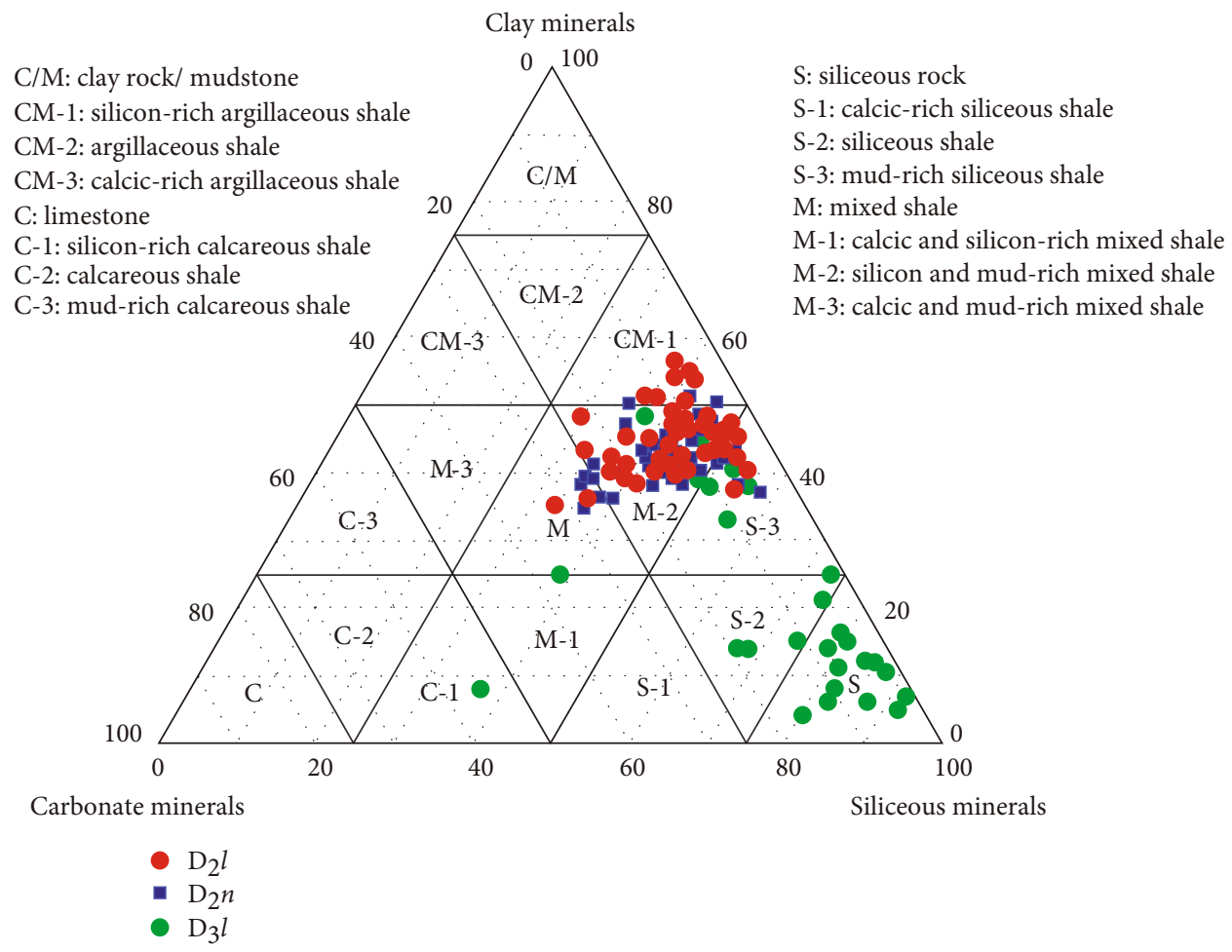

FIgURe 3: Mineral composition of the Upper-Middle Devonian samples of GY-1 well determined by XRD.

using an FEI Helios NanoLab ${ }^{\mathrm{TM}} 650$ FESEM with a resolution of $2.5 \mathrm{~nm}$ under accelerating voltage of $2 \mathrm{kV}$ and a working distance of $4 \mathrm{~mm}$.

3.5. Ultra-Low-Pressure $\mathrm{N}_{2}$ Adsorption. Ultra-low-pressure $\mathrm{N}_{2}$ adsorption analyses were carried out at $-196^{\circ} \mathrm{C}$ and relative pressure of $10^{-7}-0.995$ using a Quantachrome ${ }^{\circledR}$ Autosorb-iQ2-MP apparatus at China University of Petroleum, Beijing. Detailed information can refer to [42]. Pri- mary parameters in this measurement are surface area, pore volume, average pore diameter, etc. The surface area was calculated using the BET (Brunauer-Emmett-Teller) equation. The pore volume and pore size distribution were determined using the Barrett, Joyner, and Halenda $(\mathrm{BJH})$ method with relative pressure of 0.06-0.99. The average pore diameters were calculated using the ratio of the total adsorbed nitrogen amount to the available surface area with the assumption of cylindrical pore geometry [43]. 


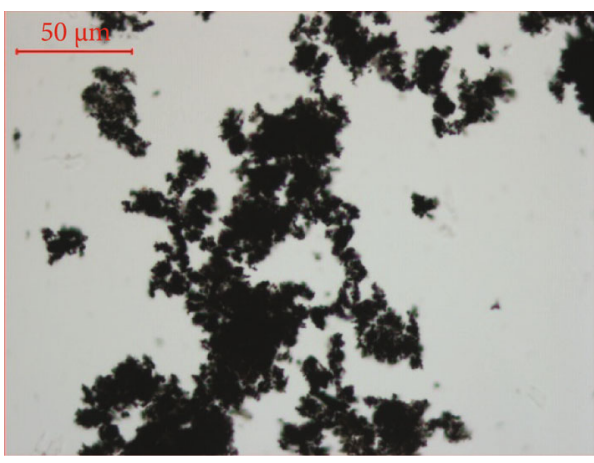

(a)

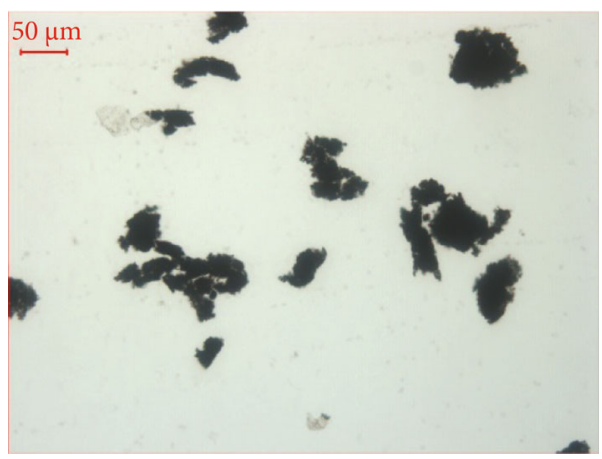

(c)

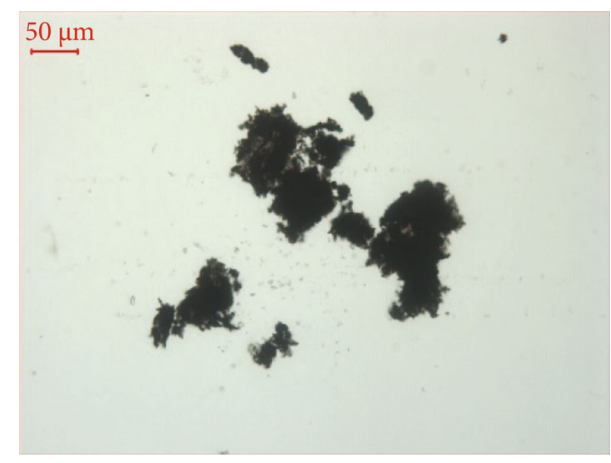

(b)

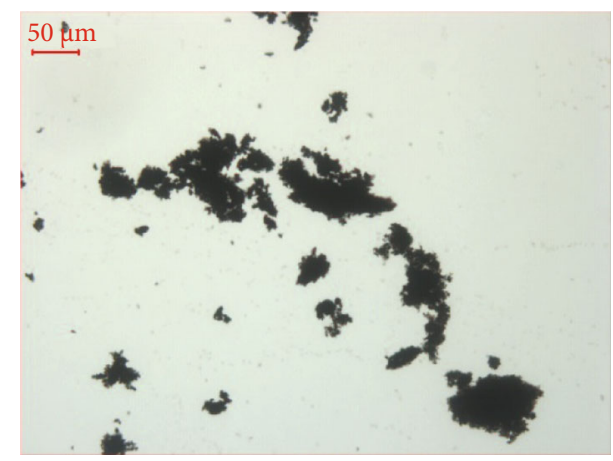

(d)

FIGURE 4: The amorphous and algal bodies of sapropelite from kerogen microscopic examination: (a) $D_{3} l$ (231 m), (b) $D_{2} l$ (579 m), (c) $D_{2} n$ $(639 \mathrm{~m})$, and (d) $D_{2} n(795 \mathrm{~m})$.

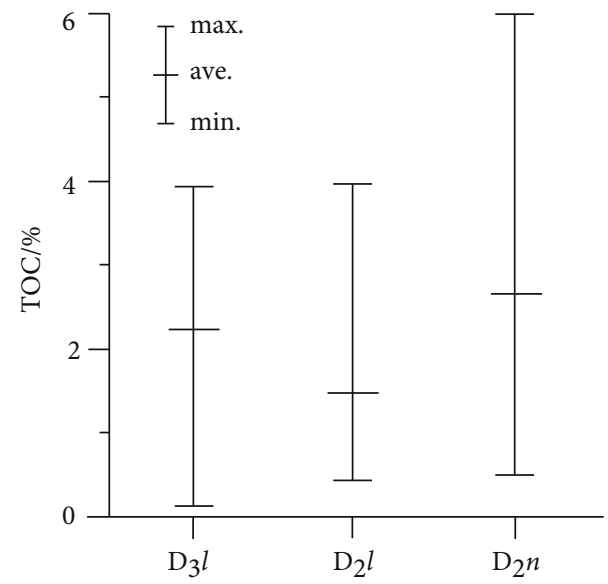

FIgURE 5: TOC statistical results of the $D_{3} l, D_{2} l$, and $D_{2} n$ source rocks.

\section{Results}

4.1. Paleoenvironment and Petrology. Basin paleoenvironment generally determines its initial productivity and redox conditions, which can be recorded by sedimentary geochemistry $[44,45]$. Main and trace elements of shale have been employed to rebuild the paleoenvironment [46], e.g., redox-sensitive elements including $\mathrm{V}, \mathrm{Co}, \mathrm{Cr}, \mathrm{Ni}, \mathrm{Mo}$, and $\mathrm{U}$, which can be used to infer redox conditions [46, 47], because these elements are typically insoluble in reducing

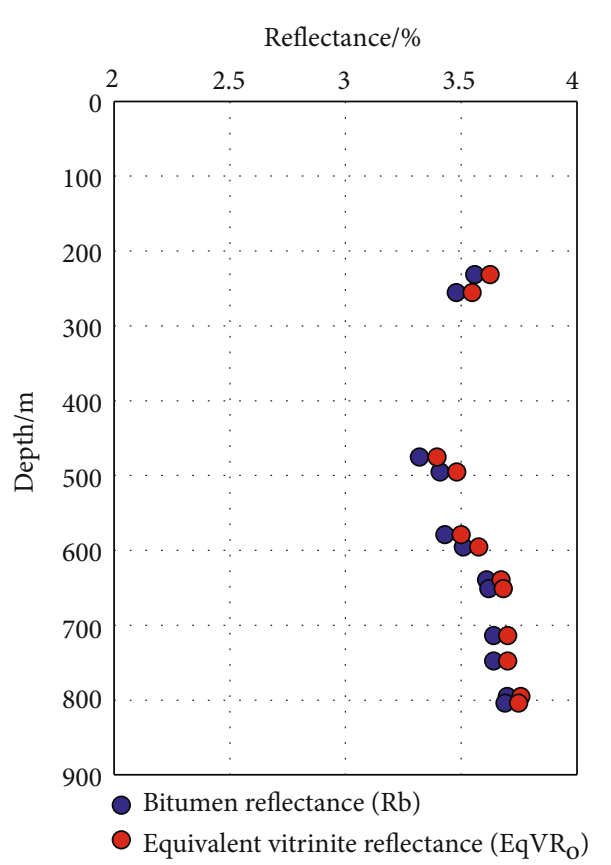

FIGURE 6: The bitumen reflectances and the determined equivalent vitrinite reflectance of GY-1 well.

environment and consequently accumulate in the anaerobic environment but loss in the oxygen-rich environment. Parameters, e.g., Ni/Co, V/Cr, and U/Th, are widely used to identify redox conditions [48]. The measurement shows 


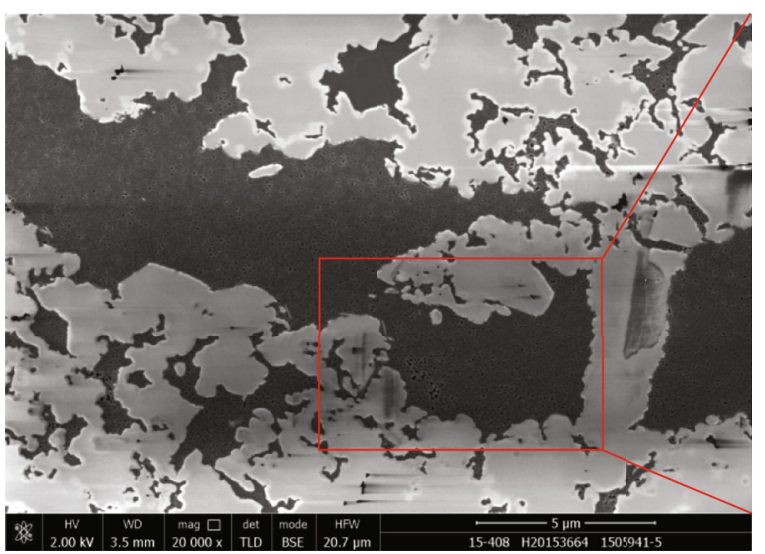

(a)

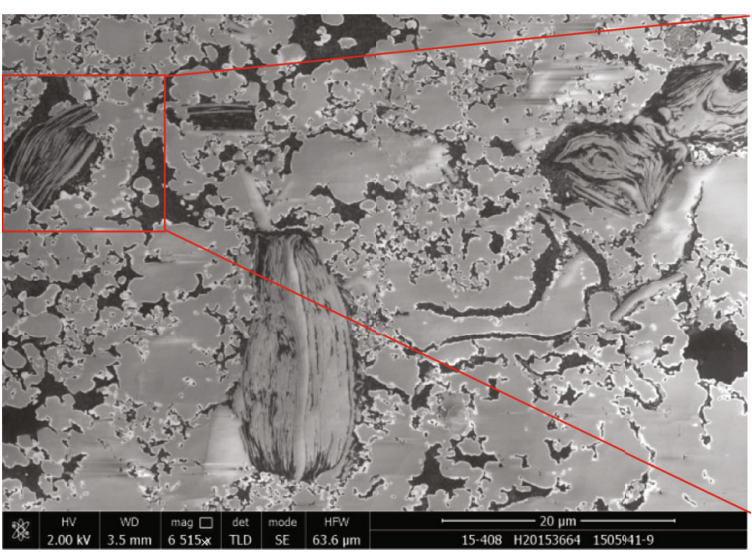

(c)

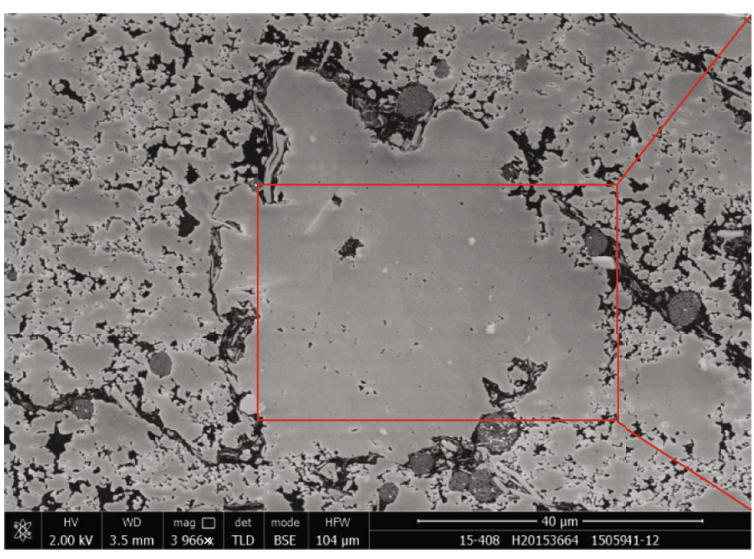

(e)

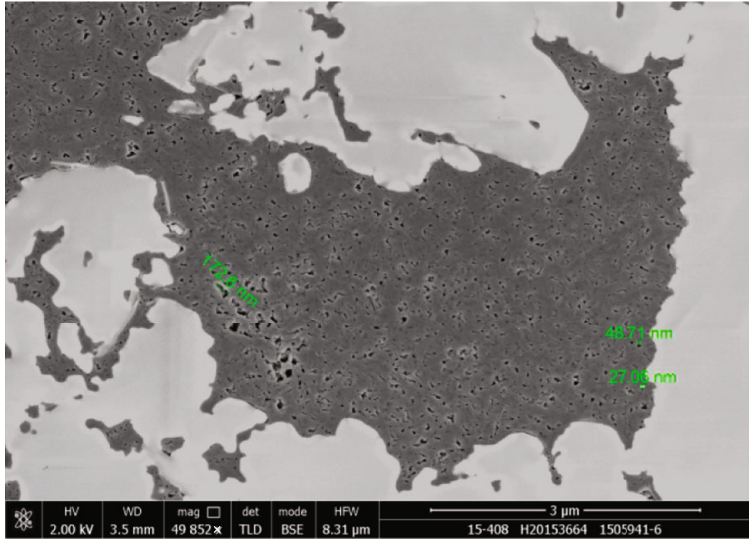

(b)

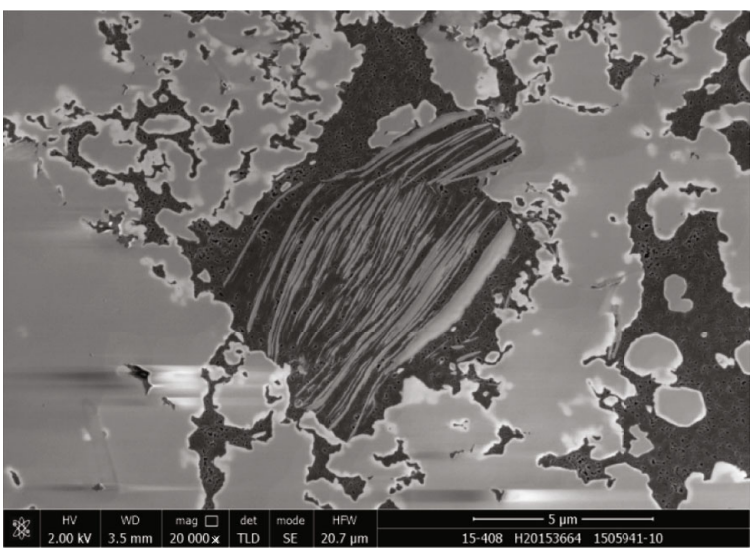

(d)

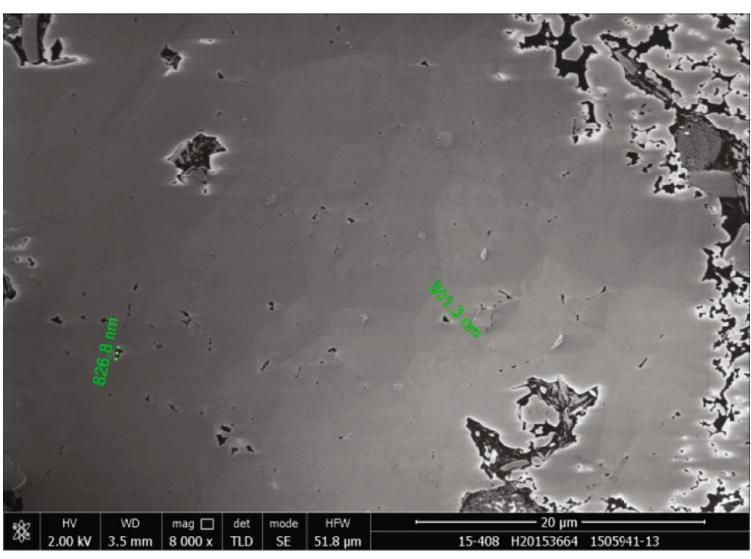

(f)

FIgURe 7: Continued. 


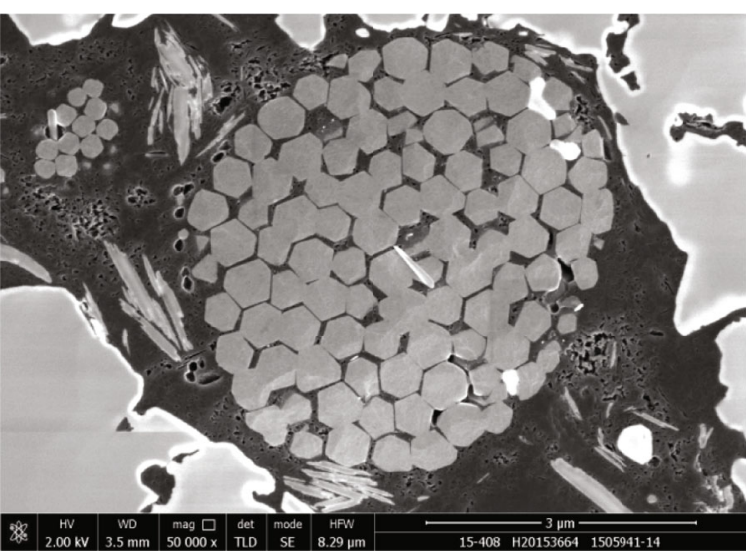

(g)

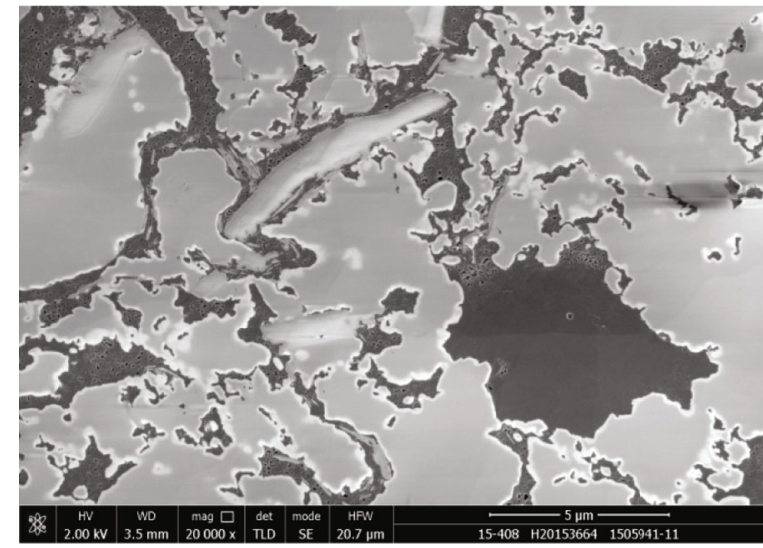

(h)

FIGURE 7: SEM images of microscopic pores from the siliceous shale (255 m of well GY-1, S-2 in Figure 3): (a, b) OM-pores, (c, d) OM-clay mineral complexes, (e, f) micropores in the quartz particles, (g) residual pores between pyrite crystals are filled with organic matter, and micropores are developed within it or/and at the edge, and (h) no OM-pores developed in some organic matter.

that the $\mathrm{V} /(\mathrm{V}+\mathrm{Ni})$ is in a range of $0.31-0.90$ with a high value in the Upper-Middle Nabiao carbonaceous shale $(636.00 \mathrm{~m}$ $771.7 \mathrm{~m}$ ) and Lower Luofu Formation (536.20-592.83 m). $\mathrm{Ni} / \mathrm{Co}$ generally ranges from 4.74 to 9.69 with a high value in the Middle-Lower Nabiao Formation (648.35 m$790.60 \mathrm{~m}$ ). U/Th varies between 0.09 and 2.03, while the value is higher in the Nabiao Formation $(684.10 \mathrm{~m}$ $807.50 \mathrm{~m}$ ) and Lower Luofu Formation (523.74 m$598.20 \mathrm{~m}$ ) and decrease toward the Upper Luofu Formation and Tangding Formation. Uranium isotope is relatively high in the Nabiao Formation and Lower Luofu Formation. Au $\left(\times 10^{-6}\right)$ varies in a similar trend with other elements, which is high in the Nabiao carbonaceous shale (Figure 2 and Table 1). These trace elements suggest that the Nabiao Formation and the Lower Luofu Formation were deposited in an anaerobic and reducing environment, while Luofu Formation and Tangding Formation were in the high-energy and well-circled environments. Also, TOC and indicators of redox environment, e.g., $\mathrm{V} / \mathrm{Cr}, \mathrm{Ni} / \mathrm{Co}$, and $\mathrm{U} / \mathrm{Th}$, follow a similar trend (Figure 2). Furthermore, tentaculites were found in both Devonian outcrop and Luofu and Nabiao core samples. These thin-wall tentaculites are typically zooplankton in deep water, indicating a deep-water deposition environment. In addition, the occurrence of considerable framboidal pyrite is a good indicator of a reductive deepwater environment. Thus, the Tangding Formation was deposited in oxygen-poor and shallow water with low TOC. Nabiao black shale was developed in an anoxic and deep-water environment with weak hydrodynamic, which contributes to the development and preservation of abundant organic matter. Different from that, the Luofu Formation was deposited in a weakly toxic environment with low organic matter abundance.

$\mathrm{X}$-ray diffraction measurement indicates that such shale gas reservoir is mineralogically composed of quartz, calcite, clay minerals, dolomite, plagioclase, siderite, and pyrite (Table 2). Liujiang Formation is characterized by the highest quartz content with a value over $90 \%$, which is primarily siliceous rock with siliceous shale, mud-rich siliceous shale, and silicon-/mud-rich shale of secondary importance. $D_{2} n$ and $D_{2} l$ are primarily siliceous/argillaceous mixed shale as well as a small proportion of siliceous argillaceous shale and argillaceous siliceous shale (Figure 3). Researchers have reported that the storage space of shales varies with lithofacies, which have a significant impact on organic matter enrichment, gas adsorption, and storage capacity [31, 49-51].

\subsection{Geochemical Analysis}

4.2.1. Kerogen Types. Kerogen's microscopic examination suggests that the Upper-Middle Devonian in the GY-1 well is dominated by the sapropelic group, with a small amount of exinite, but no vitrinite and inertinite. The sapropelic group consists mainly of amorphous bodies and algae bodies (Figure 4), while the exinite is mainly amorphous benthic algae. The determined kerogen type index indicates that the Upper-Middle Devonian is dominated by type I kerogen (Table 2).

4.2.2. TOC. TOC is highest in the $D_{2} n$ shales, ranging from $0.53 \%$ to $6.0 \%$ with an average value of $2.65 \%$ (Figure 5 ), and is lower in the $D_{3} l$ shales, ranging from $0.14 \%$ to $3.94 \%$ with an average value of $2.23 \%$. The TOC of the $D_{2} l$ shales are relatively low $(0.43 \%-3.96 \%$, averaging $1.52 \%)$. However, the lower $D_{2} l$ have relatively high TOC values (Figure 2). In general, measured TOC values indicate high hydrocarbon generation potential in these shales, and the $D_{2} n$ and the lower $D_{2} l$ are high quality that were deposited in the anoxic and weak hydrodynamic deep-water shelf.

4.2.3. Thermal Maturity. As mentioned above, the kerogen of the Devonian source rocks in the GY-1 well is dominated by amorphous solid with no vitrinite. Thus, bitumen reflectances $\left(R_{\mathrm{b}}\right)$ were measured using organic maceral analysis. The equivalent vitrinite reflectance was determined using an empirical formula from [52]: $\mathrm{EqVR}_{\mathrm{o}}=\left(R_{\mathrm{b}}+0.2443\right) /$ 1.0495. The results show that samples are thermally 


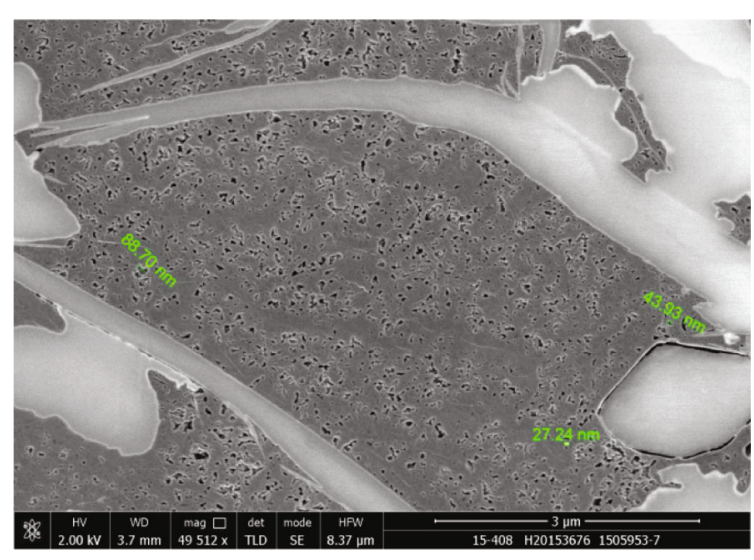

(a)

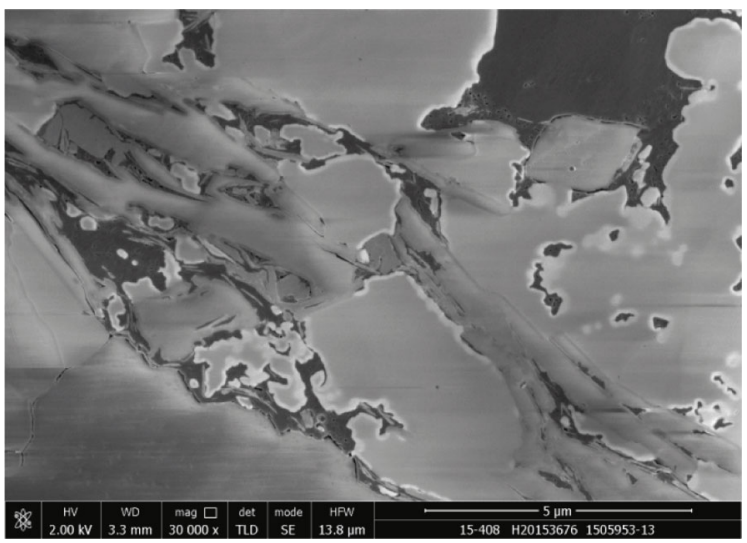

(c)

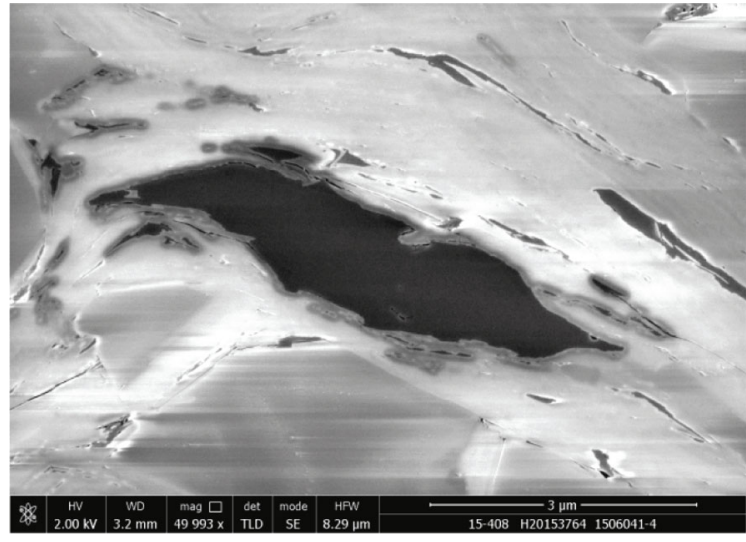

(e)

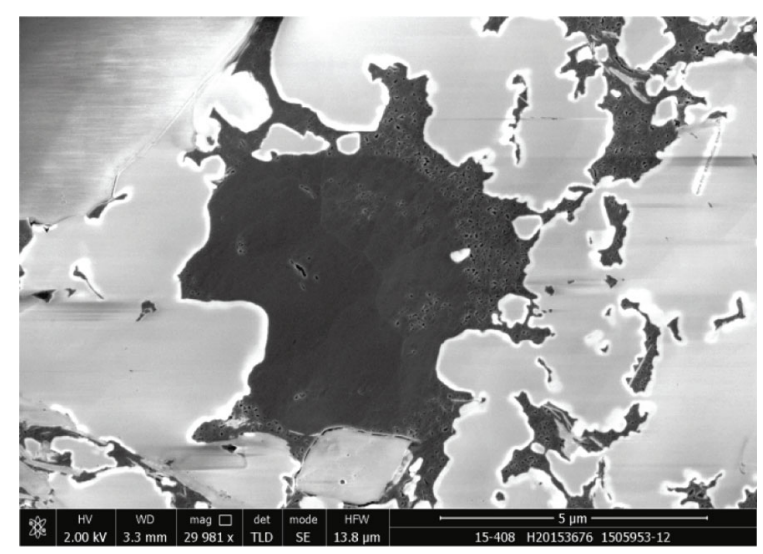

(b)

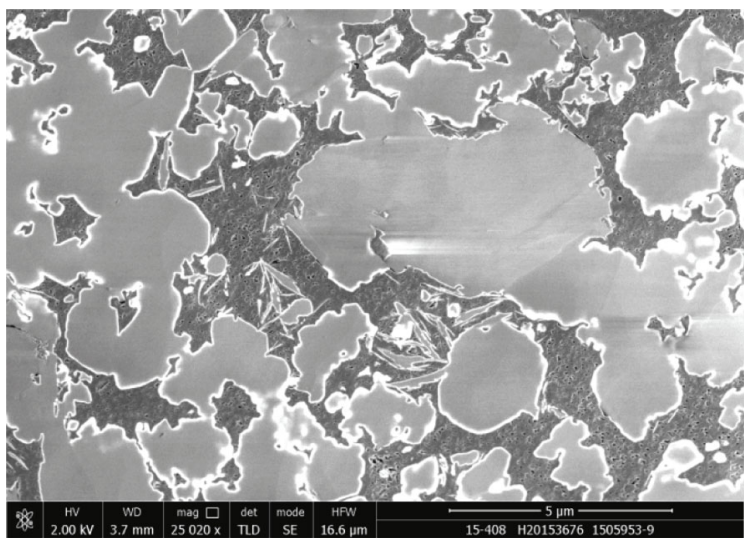

(d)

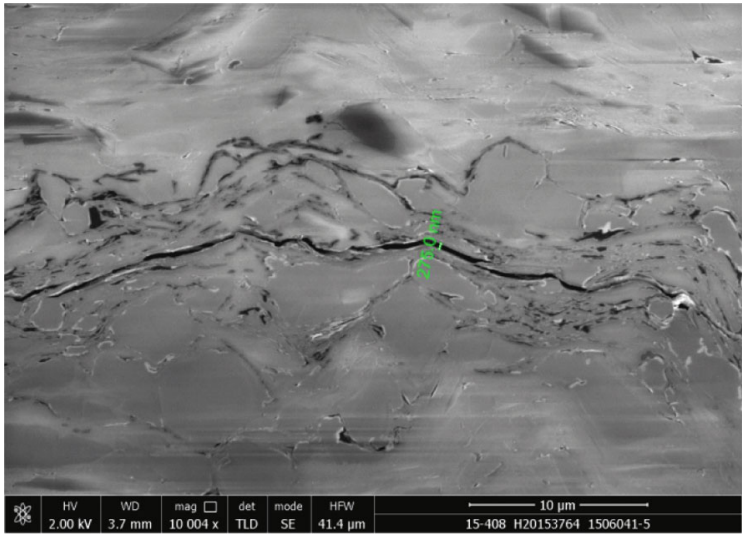

(f)

Figure 8: Continued. 


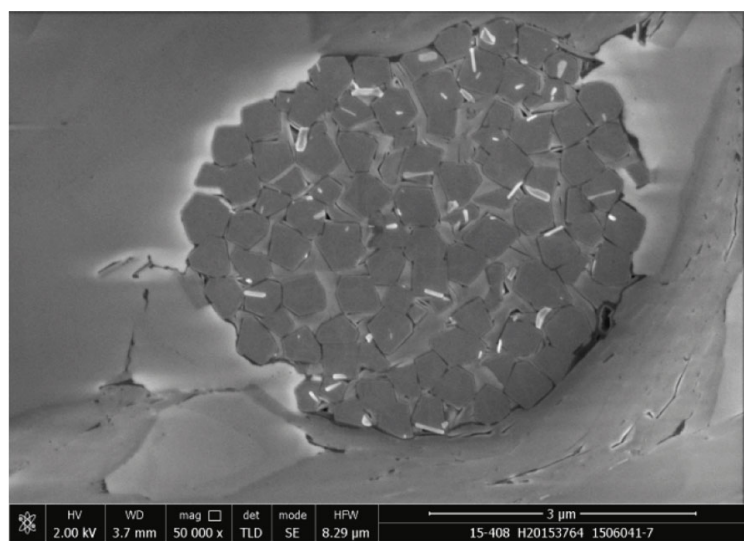

(g)

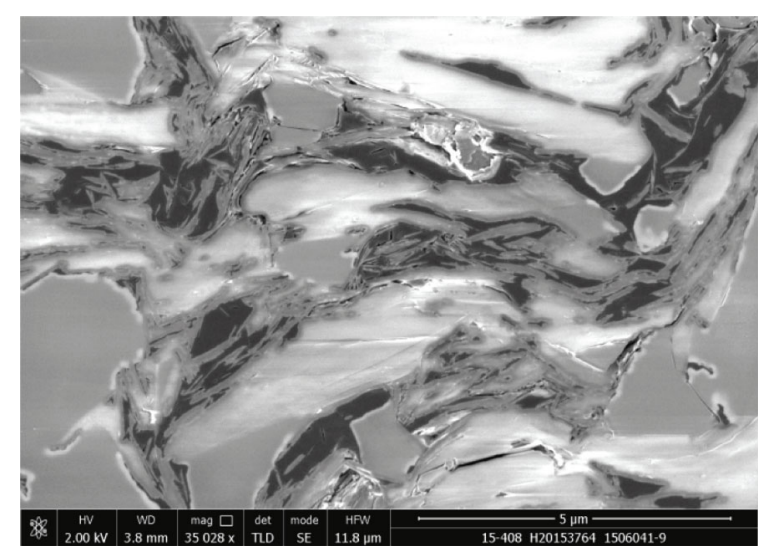

(h)

Figure 8: SEM images of microscopic pores from the siliceous lime shale (231 m of well GY-1, C-1 in Figure 3): (a) OM-pores, (b) differentially developed OM-pores, (c, e) shrunk microfractures between organic matter and minerals, (d) OM-pores and clay minerals, (f) microfractures along with minerals, (g) residual pores between pyrite crystals and a little organic matter, and (h) shrunk microfractures.

postmature to overmature with equivalent vitrinite reflectance $\left(\mathrm{EqV} R_{\mathrm{o}}\right)$ of $3.40-3.76 \%$ (Figure 6).

4.3. Pore Types. Significant effort has been devoted to identifying and describing the complex pore systems within finegrained reservoirs $[6-8,16,20,31,42]$. Pores in shale can be classified as (a) organic-matter-hosted pores, (b) interparticle pores (pores between grains and crystals), (c) intraparticle pores (pores within grains, crystals, and clay aggregates), and microfractures [7, 31]. FESEM analysis was carried out on samples from GY-1 well to observe pore types. Various types of pores with different sizes were observed in these samples, including residual primary pores in the broken particles with infill of organic matter, isolated dissolution pores in particles, interlayer pores of clay mineral supported by rigid particles, micropores within biological residues (pores in preserved tentaculite fragments), microfractures between mineral grains, intercrystalline pore of pyrite, and organic matter-hosted pores (Figures 7-9). Organic matter-hosted pores are the most common and abundant pores with various shapes and sizes, while inorganic pores are uncommon in these samples, which may be attributed to the intensive compaction and high thermal maturity. Specifically, organic pores are generally bubblelike, honeycomb-like, and crescent-like as well as an ellipse in shape; they are generally connected by tubular throats, forming a micropore system in the organic matter. According to the International Union of Pure and Applied Chemistry (IUPAC) classification, organic pores here are primarily mesopores with a pore diameter of 2-50 $\mathrm{nm}$ and macropores with pore diameter higher than $50 \mathrm{~nm}$. The occurrences of organic pores are heterogeneous, since they cannot be found in some organic matters, but are abundant in migrated organic matters, namely, solid bitumen.

\section{Discussion}

5.1. Contributors to Pore Development. Researchers have concluded that the pore structure of organic-rich shale is generally governed by diagenesis, organic matter, mineral components, thermal maturity, kerogen type, etc., depending on specific geological conditions [14, 23, 53-57]. Shale lithofacies have important controls on porosity and pore structure due to different sedimentary environments and mineralogical variations $[19,51,58-61]$. The same scenario can also be observed in our study. In the organic-rich siliceous shale, there are many micropores in the quartz grains, and the microcracks at the edges of the grains are well developed. The pores between mineral grains are generally filled with organic matter, and the OM pores are very developed. In siliceous lime shale, there are a few microcracks in the calcite grains. The pores between mineral grains are generally filled with organic matter and the OM pores are well developed. Siliceous dolomitic shale has a small number of microcracks developed along the edges of the grains. The pores between the clay mineral grains are filled with a small amount of finely dispersed organic matter with few pores developed. In carbonaceous shale, a small amount of organic matter is filled in the pores between mineral particles, and the organic matter is small and dispersed. The internal micropores of the organic matter are well developed, and the internal micropores of a small amount of massive organic matter are not developed.

In the FESEM images (Figures 7-9), considerable pores are concentrated in organic matter. Furthermore, the positive correlations between the porosity, the SSA, and the TPV and TOC confirm that organic matter contributes significantly to pore development (Figure 10, Table 3). Previous studies suggested that organic pores are not well developed in all organic matter $[18,62]$. The FESEM images show that some organic matter does not develop pores (Figure 9(c)), and/or pore development is significantly different among adjacent organic matters (Figure 8(b)). Identifying OM types and deciphering their controls on OM pore developments is one of our next priorities.

Quartz of the Devonian shales in the Guizhong Depression is primarily biogenic in origin, as inferred from the positive correlation between the quartz content and TOC 


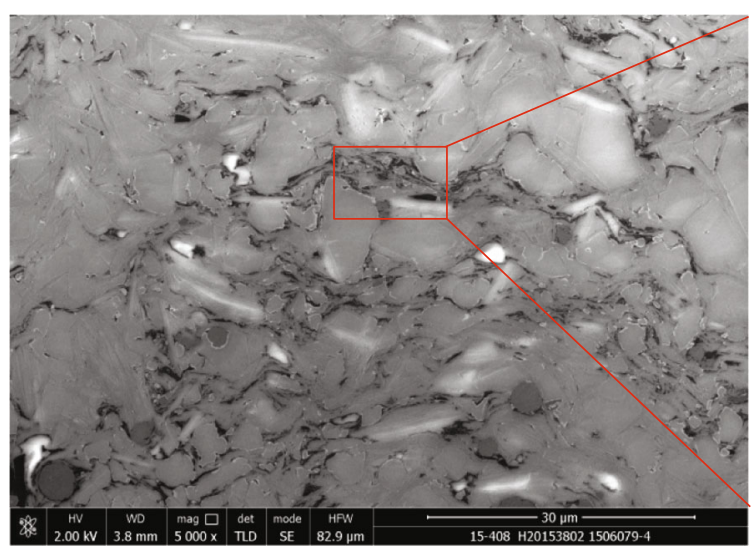

(a)

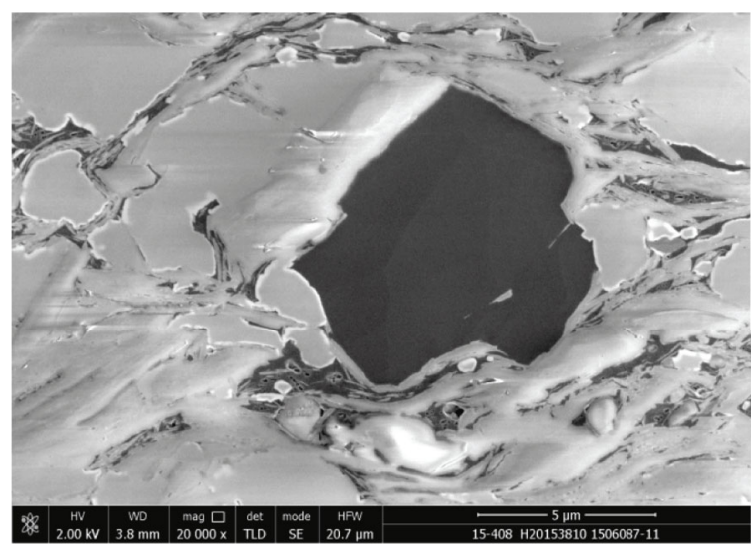

(c)

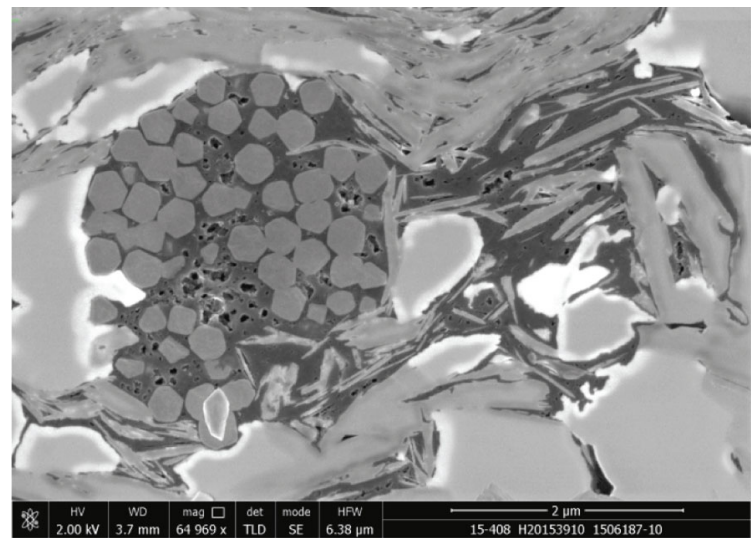

(e)

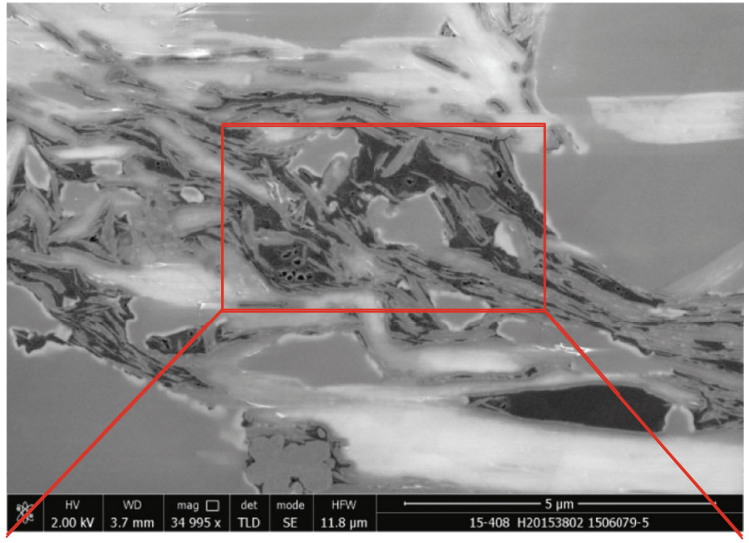

(b)

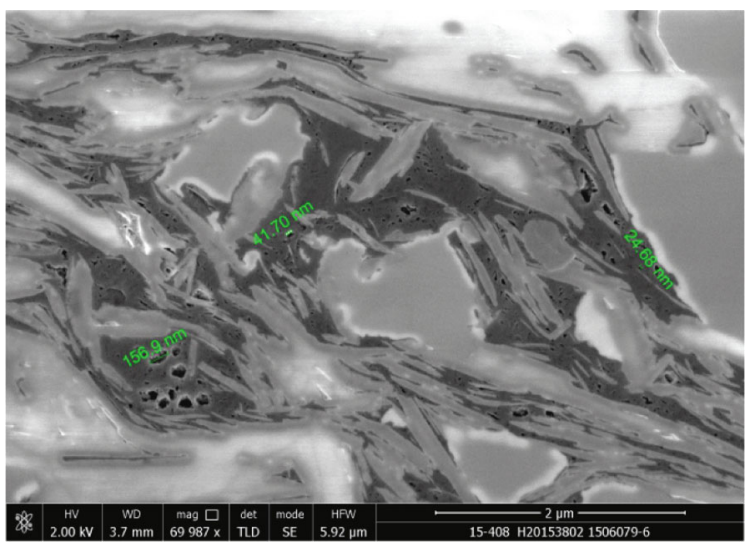

(d)

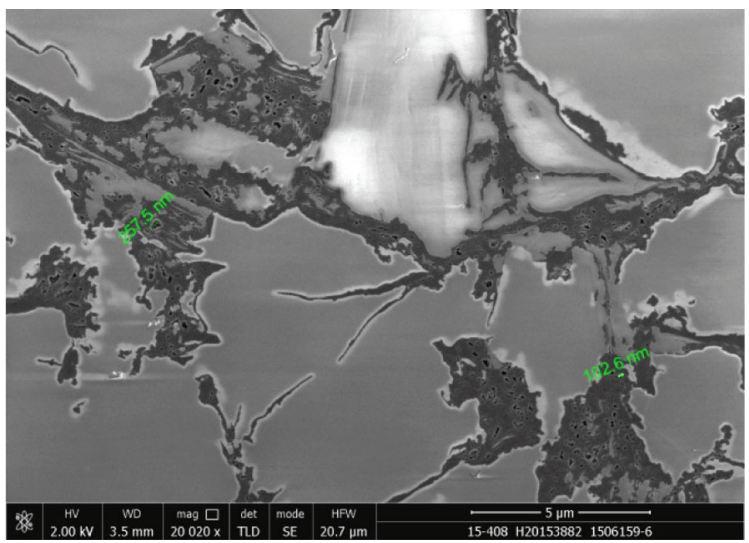

(f)

Figure 9: Continued. 


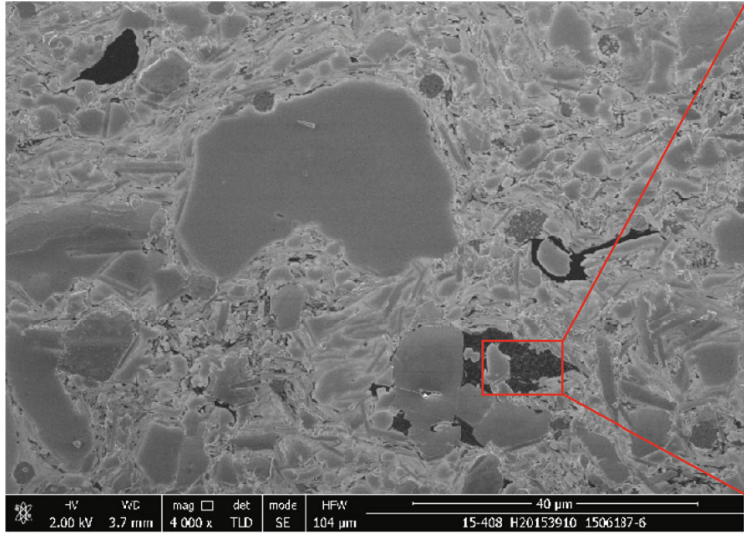

(g)

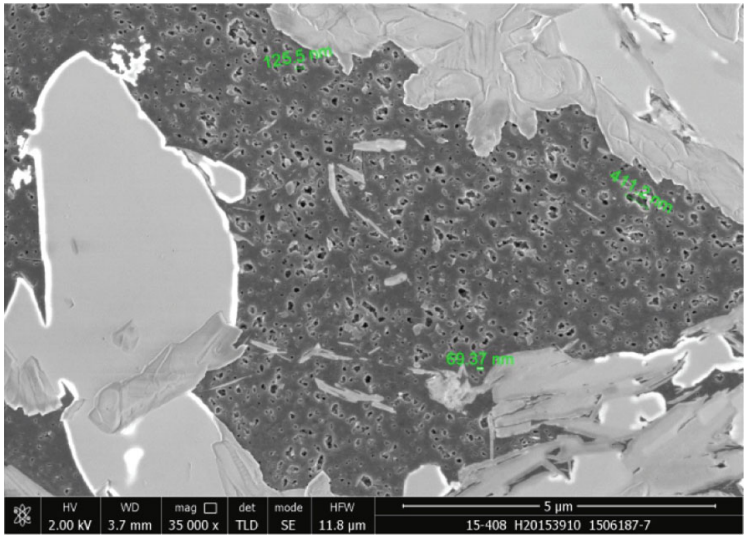

(h)

FIGURE 9: SEM images of microscopic pores from the siliceous carbonaceous shale (475 $\mathrm{m}$ of well GY-1, M-2 in Figure 3): (a, b, d, f, and h) OM-pores, (c) no OM-pores developed in the organic matter, (e) residual pores between pyrite crystals are filled with organic matter, and micropores are developed within it, and $(\mathrm{g})$ different types of organic matter.
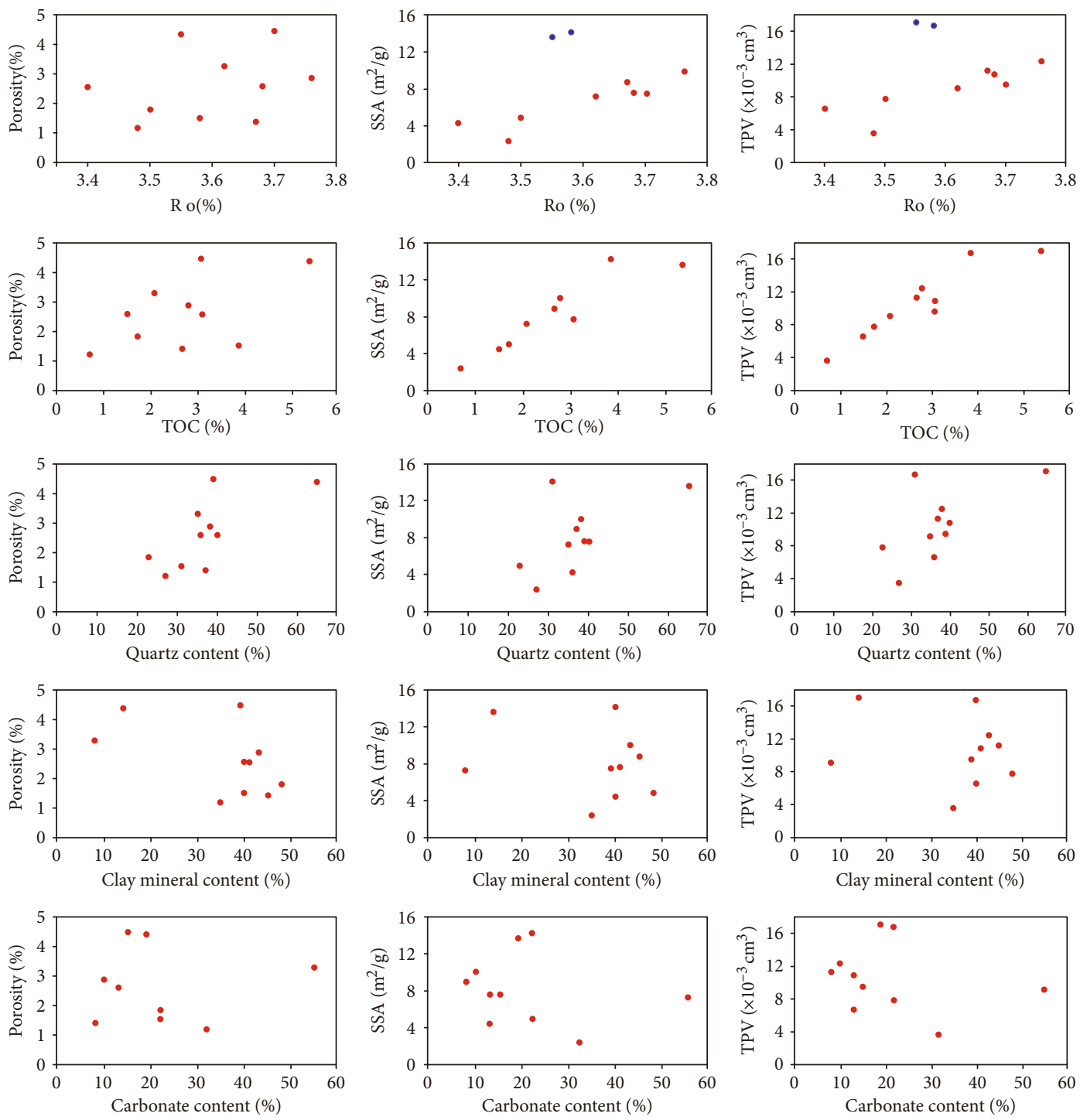

FIGURE 10: Variation of pore structure parameters (porosity, specific surface areas (SSA), and total pore volumes (TPV)) with $R_{\mathrm{o}}$, TOC, and mineral content. 


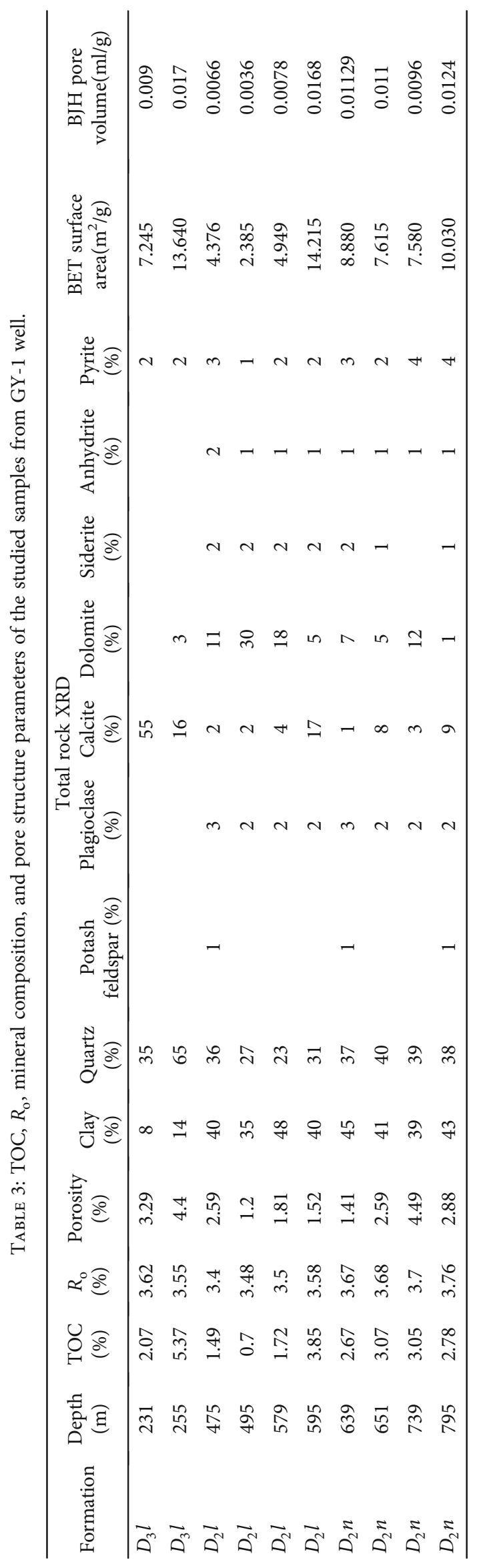




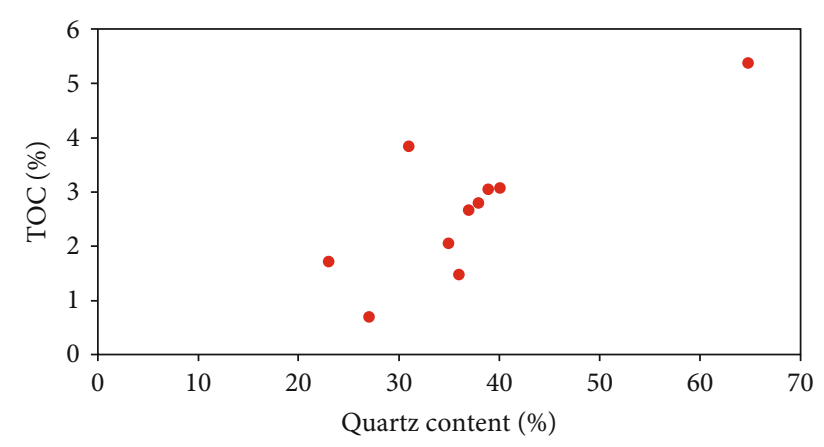

FIGURE 11: The positive correlation between the quartz content and TOC.

(Figure 11). The quartz-rich samples generally have higher porosities, SSAs, and TPVs. In addition, the brittle quartz cements provide a rigid framework that prevents pores from collapsing. Furthermore, the dissolution of quartz particles was observed (Figure 7(f)). Although pores associated with the framework of clay flakes and dissolution of carbonates can be observed, the porosity, SSA, and TPV have no clear relationship with clay or carbonate content (Figure 10). The pore volume of the shale matrix is made up of the volume provided by organic matter, clay minerals, and framework minerals [56]. Thus, this may mean that these two types of pores contribute little to the total pores of shale, compared to the pores provided by organic matter.

5.2. Organic Matter-Hosted Pores in a Postmature to Overmature Stage. Thermal maturation has been considered an important contributor to pore growth in shales due to the kerogen degradation into liquid hydrocarbon and gas [1, 13]. However, increasing burial depth and temperature enables kerogen in the shales to generate volatile hydrocarbon with increasing hydrogen and decreasing molecular mass, chemically conversing the kerogen into residual carbon with low hydrogen, which is defined as carbonization of organic matter [31, 63]. During carbonization, OMhosted pores are destroyed, merged, and collapsed [14, 64]. Specifically, previous studies show that the degradation of kerogen and dissoluble bitumen as well as methanation generally ceased with a minor increase in micropore and macropore volume at $R_{\mathrm{o}}>2.6 \%$ [65]. Organic carbonification in shale commonly occurs at $R_{\mathrm{o}}$ of $3.2 \%$ when organic pore volume begins to decrease due to the compaction and mineral infill [65]. Organic pores in marine shale are typically poor at $R_{\mathrm{o}}>3.0 \%$, with most of the pore diameter $<100 \mathrm{~nm}$ [66]. However, organic pores in this study are well grown at $R_{\mathrm{o}}$ of $3.5 \%$, and surface areas and pore volume of nanoscale pores typically increase with thermal maturity despite a similar thermal maturity range $\left(R_{\mathrm{o}} \quad 3.40 \%-3.76 \%\right)$ (Figure 9). Considerable macropores were found in samples with $R_{\mathrm{o}}>3.6 \%$. Supplementally, Cheng and Xiao [67] found that both the specific surface area and nanopore volume of organic-rich shales increased with maturity, which allowed them to keep certain porosities even in very high maturities $\left(R_{\mathrm{o}} 3.5 \%-4.0\right)$. Thus, we are more confident than some scholars about the shale pore volume in postmature to over- mature stage $[13,28,70]$ and consolidate, to a certain extent, the pore evolution diagram with increasing thermal maturity proposed by [31].

We do agree with some studies in suggesting that the macroporous in the shales are transformed into mesopores and micropores, and the organic nanopores decrease, causing nanopore volume to be displayed a decreasing trend under the condition of extremely high thermal maturity $[21,22,55]$. Of course, it cannot be denied that the evolution of organic porosity with increasing maturity is influenced by several factors [30]. Our study, however, demonstrates also that porosity at postmature to overmature stage $\left(R_{\mathrm{o}}=3.5-4.0 \%\right)$ does not change fundamentally. In other words, the porosity under the high level of maturity is satisfying for shale gas storage. Consequently, the level of maturity may not be the main controlling factor that affects shale gas content, and more attention should be paid to preservation conditions.

\section{Conclusion}

(1) Nabiao shale $\left(D_{2} n\right)$ and Lower Luofu shale $\left(D_{2} l\right)$ were deposited in anoxic and weak hydrodynamic deep-water shelf, which contributes to the development and preservation of organic matter. The Upper Luofu Formation $\left(D_{2} l\right)$ and Liujiang Formation $\left(D_{3} l\right)$ were deposited in an oxygen-poor shallow-water shelf. X-ray diffraction indicates that the lithofacies in $D_{2} n$ and $D_{2} l$ are primarily siliceous/argillaceous mixed shales as well as minor siliceous argillaceous shales and argillaceous siliceous shales

(2) The Middle-Upper Devonian shales in Guizhong Depression are organic-rich with TOCs of 0.14$6.21 \%$. TOC is highest in the Nabiao Formation $\left(D_{2} n\right)$ and Lower Luofu Formation $\left(D_{2} l\right)$, which are thermally postmature to overmature with $\mathrm{EqVR}_{\mathrm{o}}$ ranging from $3.40 \%$ to $3.76 \%$ and type I kerogen

(3) OM-pores are dominant pore types. Porosity, surface areas, and pore volumes exhibit positive correlations with TOC, $R_{0}$, and siliceous mineral contents. Considerable macropores were found in shales with $R_{\mathrm{o}}>3.6 \%$ in our study which demonstrates that porosity at postmature to overmature stage $\left(R_{\mathrm{o}}=3.5-4.0 \%\right)$ does not change fundamentally

\section{Data Availability}

All data included in this study are available upon request by contact with the corresponding authors.

\section{Conflicts of Interest}

The authors declare that they have no conflicts of interest.

\section{Acknowledgments}

This study is supported by the Daqing Oilfield Research Project (110017333001036). 


\section{References}

[1] D. M. Jarvie, R. J. Hill, T. E. Ruble, and R. M. Pollastro, "Unconventional shale-gas systems: the Mississippian Barnett shale of north-central Texas as one model for thermogenic shale-gas assessment," AAPG Bulletin, vol. 91, no. 4, pp. 475-499, 2007.

[2] K. E. Williams, "Source rock reservoirs are a unique petroleum system," in Adapted from a poster presentation given at the AAPG 2013 Annual Convention and Exhibition, Pittsburgh, Pennsylvania, USA, 2013.

[3] C. N. Zou, R. Zhu, Z. Q. Chen et al., "Organic-matter-rich shales of China," Earth-Science Reviews, vol. 189, pp. 51-78, 2019.

[4] X. N. Xie, F. Hao, Y. C. Lu et al., "Differential enrichment mechanism and key technology of shale gas in complex areas of South China," Earth Science, vol. 42, no. 7, pp. 1045-1056, 2017.

[5] C. X. Sun, H. K. Nie, W. Dang et al., "Shale gas exploration and development in China: current status," Geological Challenges, and Future Directions, vol. 35, no. 45, pp. 6359-6379, 2021.

[6] P. H. Nelson, "Pore-throat sizes in sandstones, tight sandstones, and shales," AAPG Bulletin, vol. 93, no. 3, pp. 329340, 2009.

[7] R. G. Loucks, R. M. Reed, S. C. Ruppel, and D. M. Jarvie, "Morphology, genesis, and distribution of nanometer-scale pores in siliceous mudstones of the Mississippian Barnett shale," Journal of Sedimentary Research, vol. 79, no. 12, pp. 848-861, 2009.

[8] T. Dong, N. B. Harris, K. Ayranci, C. E. Twemlow, and B. R. Nassichuk, "Porosity characteristics of the Devonian Horn River shale, Canada: insights from lithofacies classification and shale composition," International Journal of Coal Geology, vol. 141-142, pp. 74-90, 2015.

[9] M. Pommer and K. Milliken, "Pore types and pore-size distributions across thermal maturity," Eagle Ford Formation, Southern Texas, AAPG Bulletin, vol. 99, pp. 1713-1744, 2015.

[10] J. Wu, Y. Yuan, S. Niu, X. Wei, and J. Yang, "Multiscale characterization of pore structure and connectivity of WufengLongmaxi shale in Sichuan Basin, China," Marine and Petroleum Geology, vol. 120, 2020.

[11] M. Garum, P. Glover, P. Lorinczi, R. Drummond-Brydson, and A. Hassanpour, "Micro- and nano-scale pore structure in gas shale using $\mathrm{X} \mu$-CT and FIB-SEM techniques," Energy \& Fuels, vol. 34, no. 10, pp. 12340-12353, 2020.

[12] C. R. Clarkson, N. Solano, R. M. Bustin et al., "Pore structure characterization of North American shale gas reservoirs using USANS/SANS, gas adsorption, and mercury intrusion," Fuel, vol. 103, no. 45, pp. 606-616, 2013.

[13] M. Mastalerz, A. Schimmelmann, A. Drobniak, and Y. Chen, "Porosity of Devonian and Mississippian New Albany shale across a maturation gradient: insights from organic petrology, gas adsorption, and mercury intrusion," AAPG Bulletin, vol. 97, no. 10, pp. 1621-1643, 2013.

[14] M. E. Curtis, B. J. Cardott, C. H. Sondergeld, and C. S. Rai, "Development of organic porosity in the Woodford shale with increasing thermal maturity," International Journal of Coal Geology, vol. 103, pp. 26-31, 2012.

[15] C. J. Modica and S. G. Lapierre, "Estimation of kerogen porosity in source rocks as a function of thermal transformation: example from the Mowry shale in the Powder River Basin of Wyoming," AAPG Bulletin, vol. 96, no. 1, pp. 87-108, 2012.
[16] K. L. Milliken, M. Rudnicki, D. N. Awwiller, and T. W. Zhang, "Organic matter-hosted pore system, Marcellus Formation (Devonian), Pennsylvania," Bulletin, vol. 97, no. 2, pp. 177200, 2013.

[17] C. Yang, Y. Xiong, and J. Zhang, "Comprehensive understanding of OM-hosted pores in transitional shale: a case study of Permian Longtan shale in South China based on organic petrographic analysis," Gas Adsorption, and Xray Diffraction Measurements, Energy \& Fuels, vol. 33, no. 9, pp. 8055-8064, 2019.

[18] H. Nie, Z. Jin, C. Sun, Z. He, G. Liu, and Q. Liu, “Organic matter types of the Wufeng and Longmaxi Formations in the Sichuan Basin, South China: implications for the formation of organic matter pores," Energy \& Fuels, vol. 33, no. 9, pp. 8076-8100, 2019.

[19] L. Zhang, S. Lu, S. Jiang et al., "Effect of shale lithofacies on pore structure of the Wufeng-Longmaxi shale in Southeast Chongqing, China," Energy \& Fuels, vol. 32, no. 6, pp. 66036618, 2018.

[20] H. Bodhisatwa, D. A. Wood, and V. Vikram, "Pore characteristics of distinct thermally mature shales: influence of particle size on low-pressure $\mathrm{CO}_{2}$ and $\mathrm{N}_{2}$ adsorption," Energy \& Fuels, vol. 32, pp. 8175-8186, 2018.

[21] W. M. Ji, F. Hao, H. Schulz, Y. Song, and J. Q. Tian, "The architecture of organic matter and its pores in highly mature gas shales of the Lower Silurian Longmaxi Formation in the Upper Yangtze platform, South China," AAPG Bulletin, vol. 103, no. 12, pp. 2909-2942, 2019.

[22] L. Song and T. R. Carr, "The pore structural evolution of the Marcellus and Mahantango shales," Appalachian Basin, Marine and Petroleum Geology, vol. 114, 2020.

[23] C. Xue, J. Wu, L. Qiu, Q. Y. Liu, and J. Zhong, "Effect of thermal maturity on pore type and size in transitional shale reservoirs: an example from the Upper Paleozoic Shanxi Formation, Ordos Basin, China," Energy Fuels, vol. 34, no. 12, pp. 15736-15751, 2020.

[24] H. Y. Hu, "Porosity evolution of the organic-rich shale with thermal maturity increasing," Acta Petrolei Sinica, vol. 34, no. 5, pp. 820-825, 2013.

[25] J. Chen and X. Xiao, "Evolution of nanoporosity in organicrich shales during thermal maturation," Fuel, vol. 129, pp. 173-181, 2014.

[26] L. H. Xue, W. Yang, J. Zhong, Y. Xu, and G. J. Chen, "Porous evolution of the organic-rich shale from simulated experiment with geological constrains, samples from Yanchang Formation in Ordos Basin," Acta Geologica Sinica, vol. 89, no. 5, pp. 970978, 2015.

[27] Z. L. Ma, L. J. Zheng, X. H. Xu, F. Bao, and X. L. Yu, “Thermal simulation exploration on the formation and evolution of organic pores in organic-rich shale," Acta Petrolei Sinica, vol. 38, no. 1, pp. 23-30, 2017.

[28] X. Wang, Z. Jiang, S. Jiang et al., "Pore evolution and formation mechanism of organic-rich shales in the whole process of hydrocarbon generation: study of artificial and natural shale samples," Energy \& Fuels, vol. 34, no. 1, pp. 332-347, 2020.

[29] Y. Wang, L. Liu, Q. Hu, L. Hao, X. Wang, and Y. Sheng, "Nanoscale pore network evolution of Xiamaling marine shale during organic matter maturation by hydrous pyrolysis," Energy \& Fuels, vol. 34, no. 2, pp. 1548-1563, 2020.

[30] J. Klaver, G. Desbois, R. Littke, and J. L. Urai, "BIB-SEM characterization of pore space morphology and distribution in 
postmature to overmature samples from the Haynesville and bossier shales," Marine and Petroleum Geology, vol. 59, pp. 451-466, 2015.

[31] L. T. Ko, R. G. Loucks, T. Zhang, S. C. Ruppel, and D. Shao, "Pore and pore network evolution of Upper Cretaceous Boquillas (eagle ford-equivalent) mudrocks: results from gold tube pyrolysis experiments," AAPG Bulletin, vol. 100, no. 11, pp. 1693-1722, 2016.

[32] J. H. Meng, R. F. Pan, H. Chen, and X. L. Tang, "Shale gas accumulation condition and resource potential analysis of Devonian in Dian-Qian-Gui Basin," Geoscience, vol. 30, no. 1, pp. 181-191, 2016.

[33] X. Y. He, G. S. Yao, X. S. He, Z. L. Chen, and P. W. Wang, "An evaluation of depositional environment and potential of Devonian source rocks in Guizhong Depression," Acta Petrolei Sinica, vol. 32, no. 2, pp. 273-279, 2011.

[34] K. M. Wang, "Shale gas accumulation conditions of Devonian strata in Guizhong Depression," Geology in China, vol. 40, no. 2, pp. 430-438, 2013.

[35] P. W. Wang, Z. L. Chen, X. Y. He et al., "Shale gas accumulation conditions and play evaluation of the Devonian in Guizhong Depression," Oil \& Gas Geology, vol. 33, no. 3, pp. 353-363, 2012.

[36] Y. Zhou, D. Y. Zhou, Q. Q. Meng, D. W. Zhang, and Y. J. Wu, "Geological conditions and exploration potential of shale gas in Central Guangxi basin, China," Journal of Chengdu University of Technology, vol. 41, no. 5, pp. 529-537, 2014.

[37] I. Metcalfe, "Pre-cretaceous evolution of SE Asian terranes," Geological Society, London, Special Publications, vol. 106, no. 1, pp. 97-122, 1996.

[38] J. X. Cai and K. J. Zhang, "A new model for the Indochina and South China collision during the Late Permian to the Middle Triassic,” Tectonophysics, vol. 467, no. 1-4, pp. 35-43, 2009.

[39] A. Yin and S. Nie, "A Phanerozoic palinspastic reconstruction of China and its neighboring regions," in The Tectonic Evolution of Asia, A. Yin and T. M. Harrison, Eds., pp. 442-485, Cambridge University Press, Neq York, NY, USA, 1996.

[40] Z. M. Zheng, J. G. Liou, and R. G. Coleman, "An outline of the plate tectonics of China," Geological Society of America Bulletin, vol. 95, no. 3, pp. 295-312, 1984.

[41] B. J. Liu and X. S. Xu, Lithofacies Palaeogeography Atlas of Southern China, Geology Press, Beijing, 1994.

[42] G. Wang and Y. Ju, "Organic shale micropore and mesopore structure characterization by ultra-low pressure $\mathrm{N}_{2}$ physisorption: experimental procedure and interpretation model," Journal of Natural Gas Science and Engineering, vol. 27, pp. 452465, 2015.

[43] M. M. Labani, R. Rezaee, A. Saeedi, and A. Hinai, "Evaluation of pore size spectrum of gas shale reservoirs using low pressure nitrogen adsorption, gas expansion and mercury porosimetry: a case study from the Perth and canning basins, Western Australia," Journal of Petroleum Science and Engineering, vol. 112, pp. 7-16, 2013.

[44] S. J. Li, K. H. Xiao, Y. J. Wu, S. X. Long, and L. G. Cai, “Developmental controlling factors of Upper Ordovician Lower Silurian high quality source rocks in marine sequence, South China," Acta Sedimentologica Sinica, vol. 26, no. 5, pp. 872$880,2008$.

[45] H. J. Chang, X. L. Chu, L. J. Feng, J. Huang, and Q. R. Zhang, "Redox sensitive trace elements as paleoenvironments proxies," Geological Review, vol. 55, no. 1, pp. 91-99, 2009.
[46] N. Tribovillard, T. J. Algeo, T. Lyons, and A. Riboulleau, "Trace metals as paleoredox and paleoproductivity proxies: an update," Chemical Geology, vol. 232, no. 1-2, pp. 12-32, 2006.

[47] S. M. Rimmer, "Geochemical paleoredox indicators in Devonian-Mississippian black shales, Central Appalachian Basin (USA)," Chemical Geology, vol. 206, no. 3-4, pp. 373391, 2004.

[48] B. Jones and D. A. C. Manning, "Comparison of geochemical indices used for the interpretation of palaeoredox conditions in ancient mudstones," Chemical Geology, vol. 111, no. 1-4, pp. 111-129, 1994.

[49] G. Wang and T. R. Carr, "Organic-rich Marcellus shale lithofacies modeling and distribution pattern analysis in the Appalachian Basin,” AAPG Bulletin, vol. 97, no. 12, pp. 2173-2205, 2013.

[50] C. Han, Z. Jiang, M. Han, M. Wu, and W. Lin, "The lithofacies and reservoir characteristics of the Upper Ordovician and Lower Silurian black shale in the southern Sichuan Basin and its periphery, China," Marine and Petroleum Geology, vol. 75, pp. 181-191, 2016.

[51] W. Yang, R. S. Zuo, Z. X. Jiang et al., "Effect of lithofacies on pore structure and new insights into pore-preserving mechanisms of the over-mature Qiongzhusi marine shales in Lower Cambrian of the southern Sichuan Basin, China," Marine and Petroleum Geology, vol. 98, pp. 746-762, 2018.

[52] J. Schoenherr, R. Littke, and J. L. Urai, "Polyphase thermal evolution in the infra-Cambrian Ara Group (South Oman Salt Basin) as deduced, by maturity of solid reservoir bitumen," Organic Geochemistry, vol. 38, no. 8, pp. 1293-1318, 2017.

[53] S. Henares, L. Caracciolo, G. Cultrone, J. Fernández, and C. Viseras, "The role of diagenesis and depositional facies on pore system evolution in a Triassic outcrop analogue (SE Spain)," Marine and Petroleum Geology, vol. 51, no. 2, pp. 136-151, 2014.

[54] L. M. Anovitz and D. R. Cole, "Characterization and analysis of porosity and pore structures," Reviews in Mineralogy and Geochemistry, vol. 80, no. 1, pp. 61-164, 2015.

[55] X. Tang, Z. Jiang, and S. Jiang, "Effect of organic matter and maturity on pore size distribution and gas storage capacity in high-mature to post-mature shales," Energy \& Fuels, vol. 30, no. 11, pp. 8985-8996, 2017.

[56] F. Yang, Z. Ning, Q. Wang, R. Zhang, and B. M. Krooss, "Pore structure characteristics of Lower Silurian shales in the southern Sichuan basin, China: insights to pore development and gas storage mechanism," International Journal of Coal Geology, vol. 156, pp. 12-24, 2016.

[57] O. Iqbal, E. Padmanabhan, A. Mandal, and J. Dvorkin, "Characterization of geochemical properties and factors controlling the pore structure development of shale gas reservoirs," Journal of Petroleum Science and Engineering, vol. 206, 2021.

[58] S. Xu, Q. Gou, F. Hao et al., "Shale pore structure characteristics of the high and low productivity wells, Jiaoshiba shale gas field, Sichuan Basin, China: dominated by lithofacies or preservation condition?," Marine and Petroleum Geology, vol. 114, p. 104211, 2020.

[59] Q. Y. Gou, S. Xu, F. Hao, Z. G. Shu, S. He, and Z. R. Wu, "Differences in the nanopore structure of organic-rich shales with distinct sedimentary environments and mineral compositions," Energy \& Fuels, vol. 35, no. 20, pp. 1656216577, 2021. 
[60] M. A. Iqbal, R. Rezaee, G. Smith, and J. M. Ekundayo, "Shale lithofacies controls on porosity and pore structure: an example from Ordovician Goldwyer Formation, canning basin, Western Australia," Journal of Natural Gas Science and Engineering, vol. 89, 2021.

[61] F. Yang, S. Xu, F. Hao et al., "Petrophysical characteristics of shales with different lithofacies in Jiaoshiba area, Sichuan basin, China: implications for shale gas accumulation mechanism," Marine and Petroleum Geology, vol. 109, pp. 394-407, 2019.

[62] P. Luo and N. N. Zhong, "The role of residual bitumen on the pore structure of organic-rich shales from low to over mature: insight from shale and coal samples after the hydrous pyrolysis," International Journal of Coal Geology, vol. 226, 2020.

[63] Y. M. Wang, D. Z. Dong, X. Z. Cheng, J. Huang, S. Wang, and S. Wang, "Electric property evidences of carbonification of organic matters in marine shales and its geologic significance: a case study of the Lower Cambrian Qiongzhusi shale in the southern Sichuan Basin," Natural Gas Industry, vol. 1, no. 2, pp. 129-136, 2014.

[64] S. F. Wang, Z. Y. Zhang, D. Z. Dong et al., "Microscopic pore structure and reasons making reservoir property weaker of Lower Cambrian Qiongzhusi shale, Sichuan Basin, China," Natural Gas Geoscience, vol. 27, no. 9, pp. 1619-1628, 2016.

[65] D. W. Waples, "The kinetics of in-reservoir oil destruction and gas formation: constraints from experimental and empirical data, and from thermodynamics," Organic Geochemistry, vol. 31, no. 6, pp. 553-575, 2000.

[66] F. Wang, J. Guan, W. Feng, and L. Bao, "Evolution of overmature marine shale porosity and implication to the free gas volume," Petroleum Exploration and Development, vol. 40, no. 6, pp. 819-824, 2013.

[67] P. Cheng and X. M. Xiao, "Gas content of organic-rich shales with very high maturities," Journal of China Coal Society, vol. 38, no. 45, pp. 737-741, 2013. 